NOTE TO USERS

This reproduction is the best copy available.

(B)

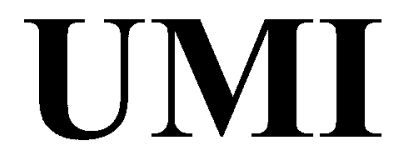


By

\section{GOVINDARADDI. BHEEMARADDI. METI}

(B.E, Karnataka University, India, 1990)

This project report is submitted to School of Graduate Studies, Ryerson University, in partial fulfillment of the requirement of the degree for Master of Engineering in the program of Civil (Environmental) Engineering, Toronto, Ontario, Canada, 2003. 
UMI Number: EC52971

\section{INFORMATION TO USERS}

The quality of this reproduction is dependent upon the quality of the copy submitted. Broken or indistinct print, colored or poor quality illustrations and photographs, print bleed-through, substandard margins, and improper alignment can adversely affect reproduction.

In the unlikely event that the author did not send a complete manuscript and there are missing pages, these will be noted. Also, if unauthorized copyright material had to be removed, a note will indicate the deletion.

(®)

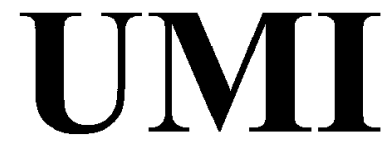

UMI Microform EC52971

Copyright 2008 by ProQuest LLC.

All rights reserved. This microform edition is protected against unauthorized copying under Title 17, United States Code.

ProQuest LLC

789 E. Eisenhower Parkway PO Box 1346

Ann Arbor, MI 48106-1346 


\section{DECLARATION OF AUTHORSHIP}

This project report entitled "Biological Removal of Nutrients Using Hybrid Technology" has been prepared and documented by the undersigned and all the sources of assistance and information have been acknowledged and referred wherever appropriate.

I further authorize Ryerson University to reproduce this report by photocopying or by other means, in total or in part, at the request of other institutions or individuals for the purpose of scholarly research.

Govindaraddi. Bheemaraddi. Meti

Department of Civil (Environmental) Engineering

Ryerson University, 2003. 


\section{Barrower's Page}

Ryerson University requires the signature of all persons using or photocopying this project work. Please be kind to sign below, and give address and date.

\begin{tabular}{|c|c|c|c|}
\hline Name of Barrower & Date & Address & Signature \\
\hline & & & \\
\hline & & & \\
\hline & & & \\
\hline & & & \\
\hline & & & \\
\hline & & & \\
\hline & & & \\
\hline & & & \\
\hline & & & \\
\hline & & & \\
\hline & & & \\
\hline & & & \\
\hline & & & \\
\hline & & & \\
\hline & & & \\
\hline & & & \\
\hline & & & \\
\hline
\end{tabular}




\begin{tabular}{|c|c|c|c|}
\hline Name of Barrower & Date & Address & Signature \\
\hline & & & \\
\hline & & & \\
\hline & & & \\
\hline & & & \\
\hline & & & \\
\hline & & & \\
\hline & & & \\
\hline & & & \\
\hline & & & \\
\hline & & & \\
\hline & & & \\
\hline & & & \\
\hline & & & \\
\hline & & & \\
\hline & & & \\
\hline & & & \\
\hline & & & \\
\hline
\end{tabular}




\section{ACKNOWLEDGEMENTS}

I would like to thank Dr. Grace Luk for contributing her time and technical support on this project work. Also, my sincere thanks to Dr. Mostafa Warith for his valuable timely advises.

There are many individuals and institutions that have made their direct and indirect contributions in completing my Masters Degree; I am in debt to all. 


\section{DEDICATION}

"Mother Nature Has Everything For Human Needs"- Mahatma Gandhi

With due reverence, dedicated to "Mother Nature", who is always perfect and tolerant 
TABLE OF CONTENTS

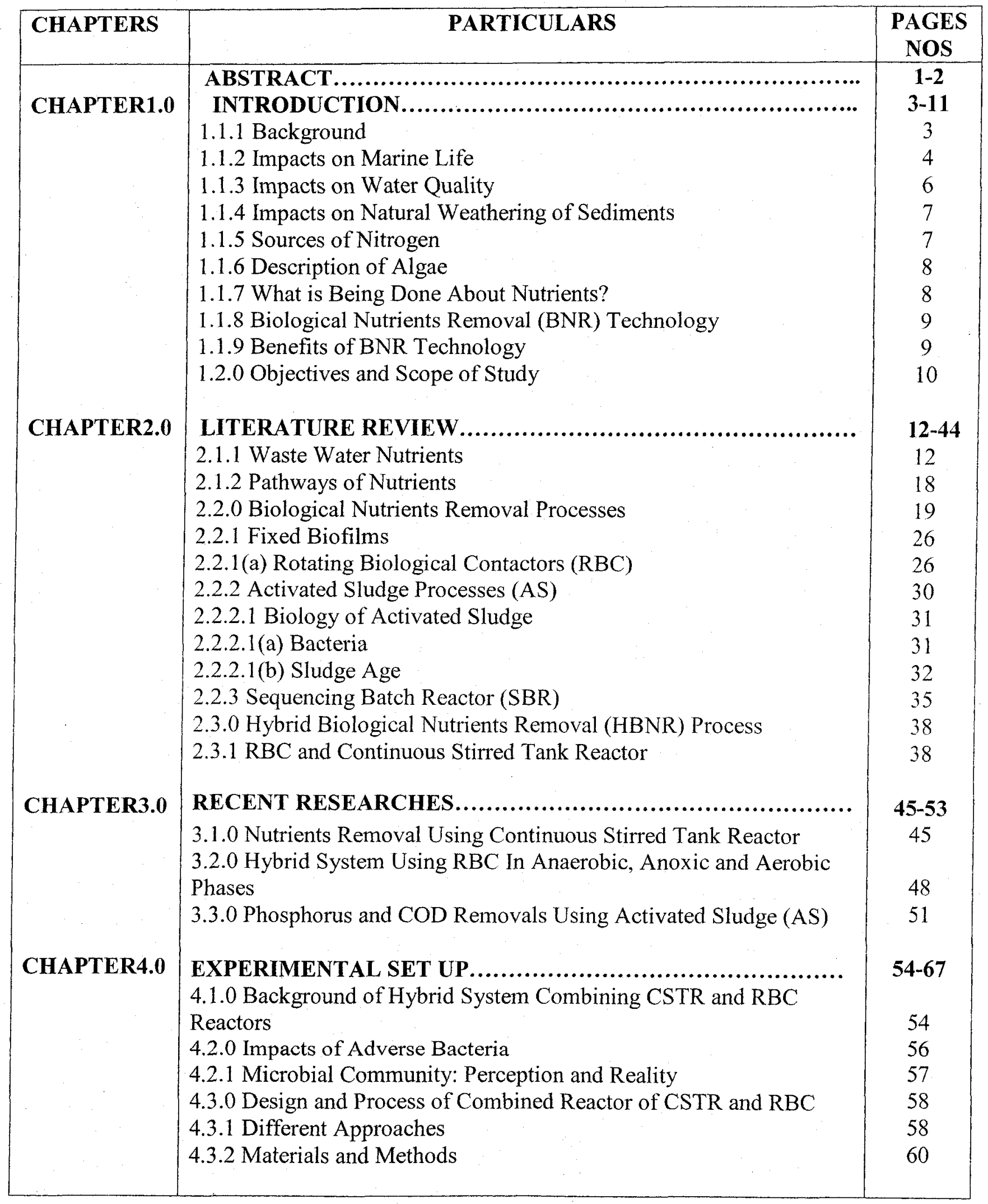

vii 


\begin{tabular}{|c|c|c|}
\hline CHAPTERS & PARTICULARS & $\begin{array}{c}\text { PAGE } \\
\text { NOS }\end{array}$ \\
\hline & $\begin{array}{l}\text { 4.3.3 Detailed Steps of Procedure } \\
\text { 4.3.4 Equipments required } \\
\text { 4.3.5 Protocol for the Analysis }\end{array}$ & $\begin{array}{l}61 \\
63 \\
64\end{array}$ \\
\hline CHAPTER5.0 & $\begin{array}{l}\text { M.1.0 Typical case for Mathematical Modeling of Biological Nutrient } \\
\text { Removal Using CSTR and RBC Reactors. }\end{array}$ & $\begin{array}{c}\mathbf{6 8 - 7 7} \\
68\end{array}$ \\
\hline CHAPTER6.0 & $\begin{array}{l}\text { EXPECTED RESULTS AND CONCLUSION........................... } \\
6.1 .0 \text { Expected Results } \\
6.2 .0: \text { Conclusion and Recommendation }\end{array}$ & $\begin{array}{l}78-79 \\
78 \\
79\end{array}$ \\
\hline & REFERENCES & 80-83 \\
\hline
\end{tabular}




\section{LIST OF TABLES}

\begin{tabular}{|l|l|l|}
\hline Table No & \multicolumn{1}{|c|}{ Title } & \multicolumn{1}{|c|}{ Page No } \\
\hline Table2.1 & $\begin{array}{l}\text { Comparison of Nutrients Loadings to Surface Water and } \\
\text { Groundwater from Various Sources in Canada, 1996 }\end{array}$ & 14 \\
Table2.2 & $\begin{array}{l}\text { Total Loadings of Phosphorus in the Final Effluents and its } \\
\text { Removal Efficiency for Various Levels of Wastewater } \\
\text { Treatment, 1996 } \\
\text { Table2.3 }\end{array}$ & $\begin{array}{l}\text { Summary of Governing Actions in the BNR Process } \\
\text { Wastewater Composition }\end{array}$ \\
Table5.2 & $\begin{array}{l}\text { Kinetic and Stoichiometric Parameters for Heterotrophic } \\
\text { Growth }\end{array}$ & 76 \\
\hline
\end{tabular}




\section{LIST OF FIGURES}

\begin{tabular}{|l|l|l|}
\hline Figure No & \multicolumn{1}{|c|}{ Title } & \multicolumn{1}{|c|}{ Page No } \\
\hline Figure1.0 & Unaffected and Affected Conditions Due to Eutrophication & 5 \\
Figure2.1 & $\begin{array}{l}\text { The Proportion of Canada's Population With Municipal } \\
\text { Wastewater Treatment Facility }\end{array}$ & 15 \\
Figure2.2 & Schematic View of a RBC Assemblage & 28 \\
Figure2.3 & Picture Shows Array of RBC Discs & 29 \\
Figure2.4 & Polyphosphate Granules Inside the Cells & 34 \\
Figure2.5 & Nitrogen Cycle & 42 \\
Figure2.6 & Phosphorus Cycle & 43 \\
Figure2.7 & Decaying Algae \\
Figure5.1 & Schematic View of CSTR and RBC Hybrid System & 69 \\
\end{tabular}




\section{SYNOPSIS}

The economic opportunity and quality of human life depend upon the continued availability of a life-sustaining environment. Understanding how we and other organisms affect, and are affected by, our environment is an important first step toward maintaining a sustainable future. As environmental engineers, we have to deal with natural systems and also expand our conceptualization of environmental engineering to include societal, legal and financial aspects. Water, by its very nature, is vital for the survival of life on the earth. If today, the struggle amongst the nations is for the resources such as oil, a survey of the United Nations suggests that in the future, it will be a struggle for drinking water. This shows how much importance we have to pay to the water and water quality to assure our future generation a life-sustainable environment to live upon.

As industrialization and population growth continues, the problem of eutrophication, which is the accelerated aging of lakes and estuaries etc., due to excess plant and algal growth has been and going to be witnessed all over the world. This is the result of discharges of nutrients like nitrogen and phosphorus to these water bodies. Hence, environmental engineers are working hard in designing the wastewater treatment system that could remove these pollutants in an efficient and cost effective way.

The components in wastewater treatment processes may be conveniently categorized as physical, chemical and biological operations, but understanding the principles governing their behavior is a prerequisite for successful process design.

Biological wastewater treatment has seen a significant growth in the last 25 years. Particular occurrence was recognition of the many events that can happen simultaneously in biological processes and the role that the design engineer has in determining which 
predominates. The impact on process design of this recognition demanded that the present and future environmental engineers begin to think in multiple events rather than compartmentalizing them. These necessitate the need for better understanding of microbiology and reactor engineering to achieve the improved results in biological wastewater treatment.

In the part of literature review, emphasis has been made to understand the nature of biochemical operations, kinetics, stoichiometry and some conflicts of the major reactions occurring in different environments and design processes. However, the important aspect of understanding and appreciating the complex interactions occurring among the microorganisms that form the ecosystems in the biological process operations has been discussed in length in the section recent research part.

Some conflicts have arisen in a single biological wastewater treatment system that simultaneously removes nitrogen and phosphorus. Therefore, resolving these conflicts and enhancing the process performance are the primary goal of this project work. An effort has been made to modify the process design and combine continuous stirred tank reactor and rotating biological contactors to overcome these conflicts.

The combined hybrid system will provide two kinds bacteria population: suspended activated sludge bacteria and biofilm bacteria. Together, these can improve the efficiency of simultaneous removal of nitrogen and phosphorus from the municipal wastewater. 


\section{CHAPTER1: INTRODUCTION}

\subsubsection{Background:}

Nutrients are essential elements for the growth and survival of organisms, and within the ecosystem, nutrients have a substantial influence on both the abundance of plant and animal life and the types and variety of species. Ever increasing population growth and various human activities have contributed in increasing the biologically available supply of two key nutrients, Nitrogen $(\mathrm{N})$ and Phosphorus $(\mathrm{P})$, in the ecosystem. An oversupply of nutrients, a condition known as eutrophication, encourages excessive plant production in aquatic ecosystems. In water bodies, increased plant productivity eventually reduces the oxygen content of the water, often to the point where fish and other species can no longer survive.

Phosphorus compounds are the main cause of eutrophication in freshwater ecosystems, but concerns have also been raised about increasing concentrations of nitrogen because of their contribution to the acidification of lakes and soils and their predominant role in the eutrophication of saltwater ecosystems.

Excessive concentrations of some nitrogen-based compounds, such as nitrates and ammonia, are toxic to plants and animals and can stimulate the growth of toxic algae in marine waters. Shellfish ingesting these algae can accumulate large amounts of toxins in their flesh can poison humans or other animals that eat them (Environment Canada, 2001). 


\subsubsection{Impacts on Marine Life:}

Although algae are the foundation on which the rest of the aquatic food chain ultimately depends; excessive algal production tends to reduce the diversity of populations in a lake and simplify its food web. The survival of species such as trout or bass becomes more tenuous, and so-called "coarse" fish species, such as carp, may come to dominate the fish population.

There are a number of reasons why an explosion of algal productivity should adversely affect many species, but the most important involve depletion of the lake's oxygen supply and the accumulation of organic debris. Plankton go through boom and bust cycles; when populations die off, their decomposition draws large amounts of dissolved oxygen from the water, causing stress to fish and invertebrates. Large quantities of plants can also affect the oxygen supply on a daily basis. Aquatic plants produce oxygen during the daytime through photosynthesis; at night, they consume oxygen, so that dissolved oxygen levels fall very low where plants are abundant. In addition, the overabundance of organic matter caused by excessive algal populations can smother the lake bottom and reduce the diversity of bottom-dwelling organisms.

Organic matter also accumulates in crevices between rocks where decay can consume enough oxygen to impair the survival of fish eggs. As organic matter accumulates in sediments, nuisance accumulations of aquatic rooted plants are more likely to occur (Environment Canada, 2001).

In more simplistic way, visual effects of eutrophication include muddled and discolored water, excessive algae and bacteria production, and aquatic organisms killed 
by oxygen depletion. Thus, biodiversity in these aquatic ecosystems is often disturbed and depleted.

Water saturated with oxygen will have a DO of $7-9 \mathrm{mg} / \mathrm{L}$, depending on the temperature and altitude. Typically, higher marine life in shallow (costal and river) waters can survive at DO level of $4 \mathrm{mg} / \mathrm{L}$ and higher, but a healthy marine population requires DO level of $6.0 \mathrm{mg} / \mathrm{L}$ or higher to ensure a healthy spawning environment.

The following figure illustrates both the cases of unaffected and affected water bodies by eutrophication.

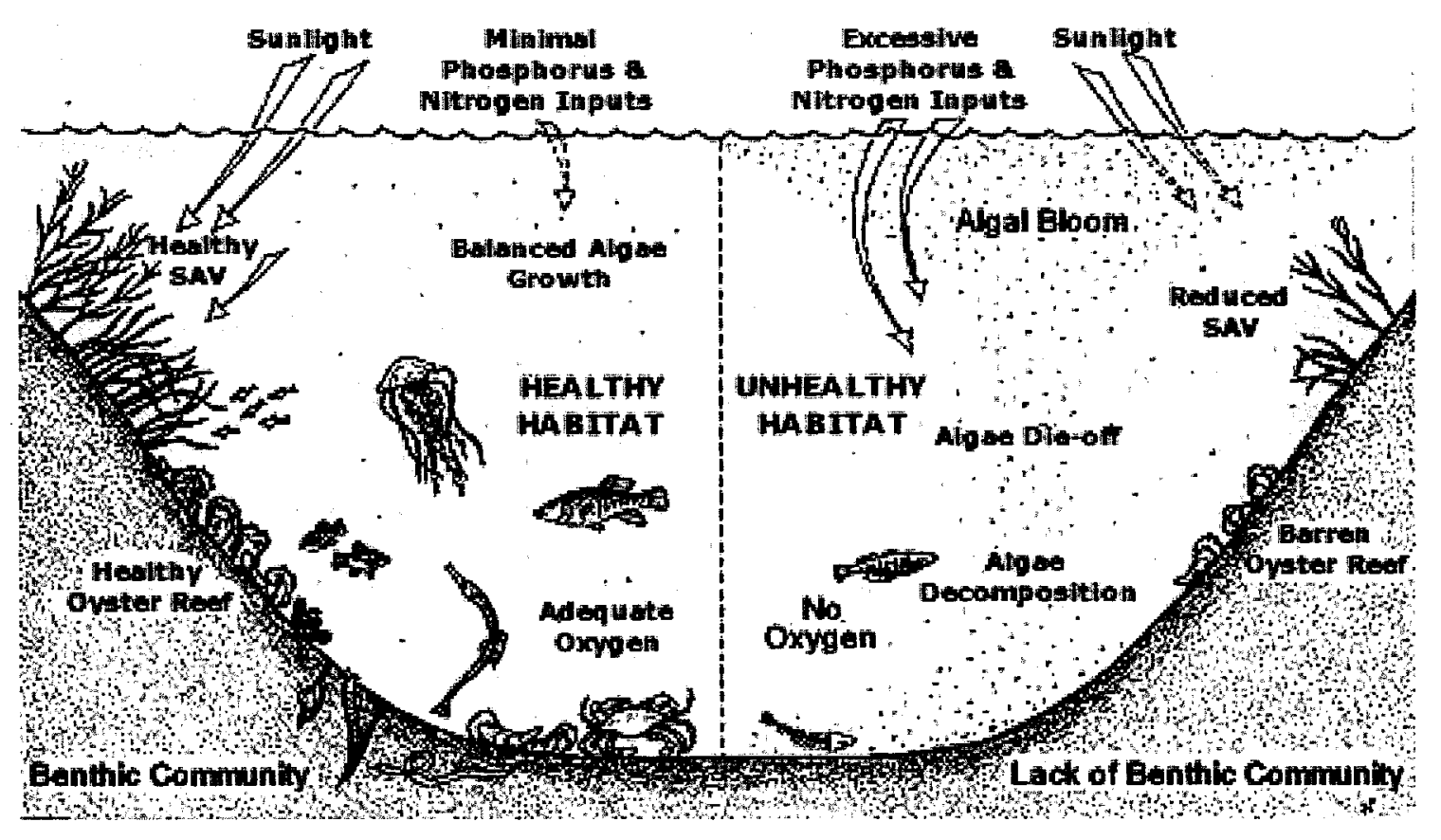

Figure1.0: Unaffected and Affected Conditions Due to Eutrophication

(After: Chesapeake Bay Program, http://www.chesapeakebay.net) 


\subsubsection{Impacts on Water Quality:}

Deoxygenation is most severe in the cold, bottom waters of eutrophic lakes. In early summer, solar radiation warms the surface waters of lakes in temperate climates, resulting in the formation of warm and cold layers. Because the solar radiation is rapidly absorbed in the upper portion of the lake, the deeper waters remain cold. This cold bottom layer, known as the hypolimnion, is denser than the overlying warm water and thus does not mix easily with it. As a result, when oxygen is consumed in the hypolimnion, it cannot be replaced by diffusion from the warmer water above it.

When bacteria feed on the abundance of organic matter that falls to the bottom of eutrophic lakes, they can rapidly use up the hypolimnion's limited and finite oxygen supply.

If the oxygen concentration in a lake's hypolimnion gets too low, organisms may die or be forced out of the hypolimnion. Under less severe circumstances, persistently low-oxygen concentrations can cause coldwater species that require high concentrations of dissolved oxygen (for example, trout and sculpins) to be replaced by warm water species (for example, walleye, pike, and smallmouth bass), with lower oxygen requirements (Environment Canada, 2001). 


\subsubsection{Impacts on Natural Weathering of Sediments:}

A partial or complete lack of oxygen in the hypolimnion can add to a lake's nutrient loadings by causing phosphorus to be released from the bottom sediments. The phosphorus then diffuses upward into the surface water and stimulates further algal production. In shallow lakes, decades of pollution can cause the release of phosphorus from bottom sediments even under oxygenated conditions. The release of phosphorus from sediments can slow the recovery of a lake after external loadings have been reduced (Environment Canada, 2001).

\subsubsection{Sources of Nitrogen:}

Major anthropogenic sources of nutrients are municipal and rural wastewaters, agricultural runoff, and industrial wastes. Much of it eventually ends up in surface waters, through direct discharge, as in the case of municipal and industrial effluents, through groundwater and surface runoff, as in the case of nutrients leached from agricultural croplands, or through atmospheric deposition, as in the case of particles and gases emitted to the air from croplands, industrial smokestacks, and vehicle tailpipes (Environment Canada, 2001). 


\subsubsection{Description of Algae:}

The chemical composition of algae can be represented by $\mathrm{C}_{106} \mathrm{H}_{263} \mathrm{O}_{110} \mathrm{~N}_{16} \mathrm{P}$ (Randall et al., 1992). According to this component ratio, each gram of phosphorus is completely assimilated by algae to manufacture new biomass from photosynthesis and inorganic elements: biomass of 111 grams with COD of 138 grams would be produced. It is possible for either $\mathrm{N}$ or $\mathrm{P}$ is to be the nutrient that limits algal growth and 1 gram of $\mathrm{N}$ could potentially stimulate the manufacture of 16 grams of algal biomass, which would be equivalent to 20 grams of COD.

Thus the discharge of $1 \mathrm{mg} / \mathrm{I} P$ could potentially result in COD equivalent to $138 \mathrm{mg} / \mathrm{l}$. Then $1 \mathrm{mg} / \mathrm{l} \mathrm{N}$ could result in potential production of COD equivalent to 20 $\mathbf{m g} / \mathbf{l}$; this is less than the potential production by $\mathrm{P}$, so if the same amount of $\mathrm{N} \& \mathrm{P}$ should be removed, $\mathrm{P}$ should be removed first. Both of them still greater than the COD of the organics in the untreated wastewater \& should be removed reasonably (Su et al., 1997).

\subsubsection{What is Being Done About Nutrients?}

Controlling nutrients is a potential costly issue due to the many sources of nutrient pollution. Sewage treatment plants have ways of removing the nutrients from the wastewater, which can reduce the amount of nutrient pollution entering the water bodies. The Ministry of Environment, Government of Ontario has started incorporating limits on nutrients discharges from wastewater treatment plants in to water bodies.

However, biological method of nutrients removal is proving to be a cost effective process \& can be implemented to existing wastewater treatment plants. 


\subsubsection{Biological Nutrients Removal (BNR) Technology:}

Biological nutrients removal processes are well-established technologies for treating domestic wastewater. Nevertheless, in Hybrid systems like combination of two processes, high nitrogen removal rate can be achieved by the aid of the long solids retention time (SRT) biofilm on the rotating biological contactors (RBC). The suspended solids in the systems can be operated at short SRT without decreasing the nitrogen removal capacity to progress phosphorus removal rate to the degree of statutory requirements.

\subsubsection{Benefits of BNR Technology:}

Although, there are several benefits of BNR technologies, the most important ones are given as below:

- Regulatory compliance through reliable and consistent removal of nitrogen and phosphorus

- Biological process uses naturally occurring, environmentally acceptable microorganisms.

- Minimum or no chemical addition

- Efficient nutrient removal in warm and cold climates

- Flexible design to accommodate variations in organic and nutrient loading

- No chemical sludge

- Reduced sludge handling costs

- Nutrient-rich sludge suitable for beneficial end use

- Use of nitrate to remove part of the influent BOD 
- Optimum use of existing facilities

- Less energy consumption, etc (Grady Jr et al., 1999).

\subsubsection{Objectives and Scope of Study:}

The object of this project work is to develop and study a new hybrid biological nutrient removal (HBNR) process in treating domestic wastewater from municipal treatment plants and evaluate the concept to resolve the conflicts in solids retention time (SRT) of conventional biological nutrients removal processes. The hybrid system is formed by the combination of continuous stirred tank reactor (CSTR) and rotating biological contactors (RBC).

Scope of this works is limited only to wastewater from municipal wastewater treatments for tests \& experiments, and other sources like sludge or industrial wastewater fall beyond the study boundaries.

In 1975, Barnard adopted a single sludge system to remove both nitrogen and phosphorus without adding any chemicals, but conflict arises when employing such a single sludge system to simultaneously remove nitrogen and phosphorus. First, growth of nitrifiers and denitrifiers is slower than that of heterotrophic bacteria and longer SRT must be adopted if improvement in the nitrification and denitrification is required.

Correspondingly, the system must be operated using a shorter SRT if phosphorus removal must be undertaken. The conflict arises during the operation of SRT. Second, the anoxic reactor is typically placed behind the anaerobic rector and the short chain fatty acids (SCFA) are utilized primarily for the phosphate release in the anaerobic reactor. Comeau (1986) suggested combining the clarified wastewater emitted from a digested 
sludge reactor with the wastewater influent to increase the amount of SCFA as well as improve the phosphate release and denitrifcation rate. Biofilms (e.g., RBC) have a long sludge age and high biomass concentration and stability in operation, hence, can be used to resolve the above mentioned SRT conflict in combination with suspended growth of activated sludge system (e.g., CSTR) to remove nitrogen and phosphorus simultaneously.

The basic operational conditions for the experiments shall be as below:

- SRT: 10-12 days

- Hydraulic Retention Time (HRT): 10-11 hours

- Temperature: 20-22 C

With other relevant experimental details, HBNR can achieve a removal efficiency of about 95\% TKN, 70\% T-N and 95\% T-P (Su et al., 1996 and 1997). 


\section{CHAPTER2: LITERATURE REVIEW}

\subsubsection{Waste Water Nutrients:}

The term nutrients in wastewater is usually referred to nitrogen and phosphorus compounds that are released to environment as a result of human activities. Nutrients are essential to natural water bodies, because they provide the raw material for the growth of algae, the food sources of zooplankton, which, in turn, are eaten by fish. The concentration of nutrients in a lake is determined by the interplay of the magnitude, timing and bioavailability of the nutrient load, the rate of water supply compared to the volume of the lake (flushing time), and the depth of the lake.

Lakes can absorb certain amount of nutrients but an oversupply of nutrients, a condition known as eutrophication, encourages excessive plant production in aquatic ecosystems. In lakes and rivers, increased plant productivity eventually reduces the oxygen content of the water, often to the point where fish and other species can no longer survive. Phosphorus compounds are the main cause of eutrophication in freshwater ecosystems and nitrate is believed to be partly responsible for declines in amphibian populations in Canada, and adverse effects on organisms include poor larval growth, reduced body size, and impaired swimming ability.

Nutrient additions have led to higher risks to human health from the use of waters contaminated with toxic algal blooms and consumption of tainted shellfish. Aesthetic enjoyment of the water may be impaired by turbidity, discoloration, foaming, and odor, while long strands of nuisance algae such as Cladophora can restrict swimming, foul fishing gear, damage boat motors, and impede navigation. In some cases, municipalities and industries may have to face higher maintenance costs to clear clogged intake pipes, 
and communities may have to pay for additional filtration of drinking water to reduce taste and odor problems.

In Canadian ecosystem, nutrients became a major environmental issue during 1970 due to eutrophication of Lake Erie. Monitoring the release of phosphates and laundry detergents combined with better sewage treatment helped to bring the problem under control. However, in various parts of Canada, inputs of nutrients from other sources have increased at alarming rate that a stringent regulatory action may be necessary to protect further damage to the ecosystem.

Major anthropogenic sources or causes of nutrients are urbanization, industrialization, and intensive agriculture. Municipal wastewater is the largest point source of nitrogen and phosphorus to the Canadian environment. In 1996, an estimated 6 thousand tonnes of total phosphorus and 80 thousand tonnes of total nitrogen were released to lakes, rivers and coastal waters from Canadian households, as shown in table 2.1. This loading occurred despite the fact that $73 \%$ of Canadians were served by municipal sewer systems, as in figure 2.1 and at least $94 \%$ of the wastewater collected by sewers received primary or higher treatment, as shown in table 2.2. 
Table 2.1: Comparison of nutrient loadings to surface water and groundwater from various sources in Canada, 1996

\begin{tabular}{|c|c|c|}
\hline Nutriant source & $\begin{array}{l}\text { Phosphorus loading } \\
\text { (thousands of tonnes per year) }\end{array}$ & $\begin{array}{l}\text { Nitrogen londing } \\
\text { (thousands of tonnes per year) }\end{array}$ \\
\hline \multicolumn{3}{|l|}{ Municipal } \\
\hline $\begin{array}{l}\text { Municipal wastewater } \\
\text { treatrment plants }\end{array}$ & 5.6 & 80.3 \\
\hline $\begin{array}{l}\text { Sewers (storm and combined } \\
\text { sewer overflows) }\end{array}$ & 2.3 & 11.8 \\
\hline Septic systems & 1.9 & 15.4 \\
\hline Industry & 2.0 & 11.8 \\
\hline \multicolumn{3}{|l|}{ Agriculture } \\
\hline Inputs & 442 & 2784 \\
\hline Removed & 386 & 2491 \\
\hline Runoff & $n / a$ & $\pi / a$ \\
\hline Aquaculture & 0.5 & 2.3 \\
\hline Atmospheric deposition & $\pi / a$ & $182\left(\mathrm{NO}_{3}^{-}\right.$and $\left.\mathrm{NH}_{4}^{+}\right)$. \\
\hline
\end{tabular}

(After: Chambers et al. 2001, Environment Canada) 


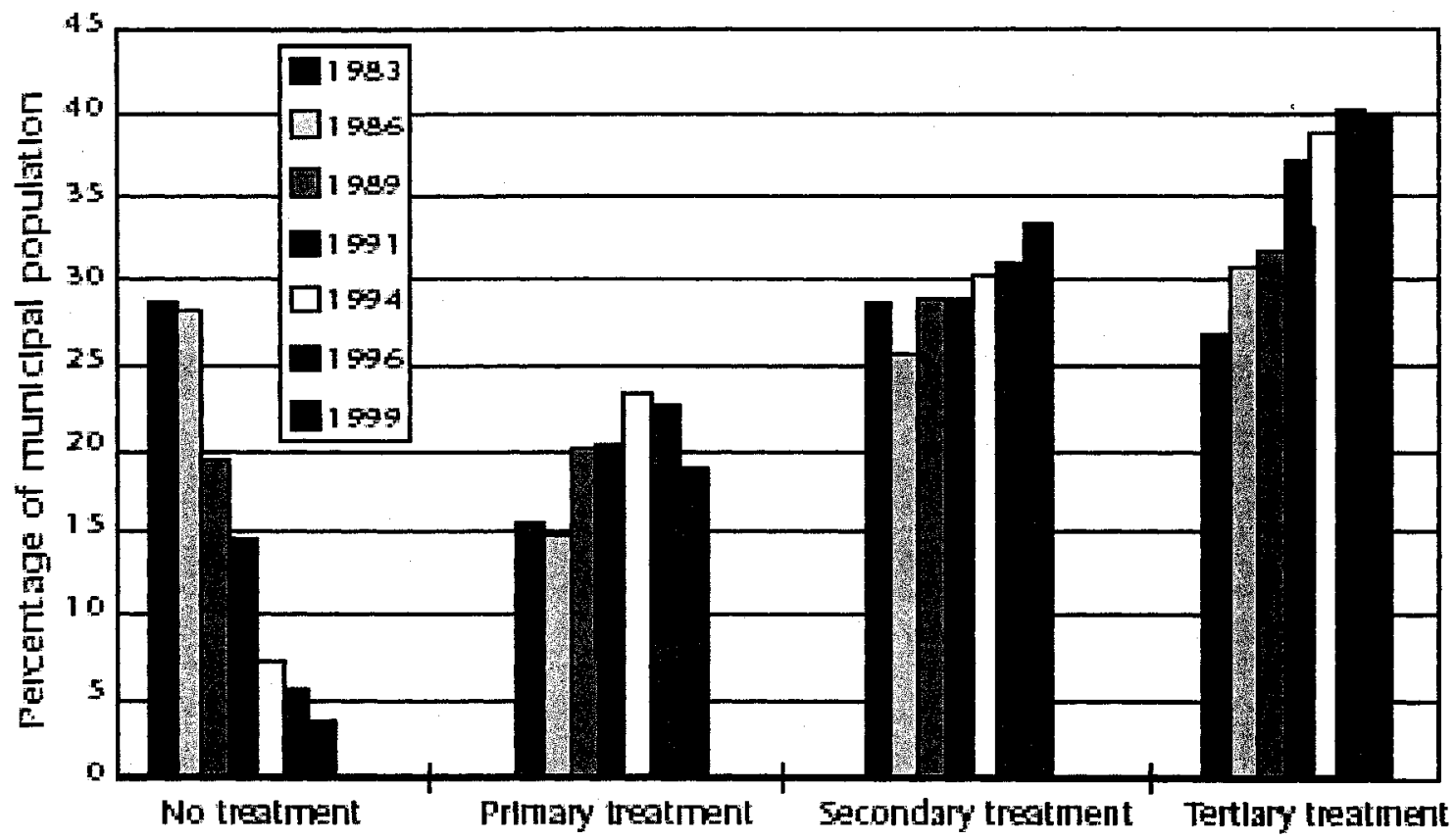

Figure2.1: The proportion of Canada's population with municipal wastewater treatment facility, 1983-1999.

(After: Environment Canada 2001, Municipal Water Use Database) 
Table 2.2: Total loadings of phosphorus in the final effluent and its removal efficiency for various levels of wastewater treatment 1996

\begin{tabular}{|c|c|c|c|c|}
\hline $\begin{array}{c}\text { Treatment } \\
\text { type }\end{array}$ & $\begin{array}{c}\text { Phosphorus } \\
\text { removal? }\end{array}$ & $\begin{array}{l}\text { Number of } \\
\text { facllitler } \\
\text { sampled }\end{array}$ & $\begin{array}{c}\text { Effluent total } \\
\text { phosphorus bad } \\
\text { (grams par } \\
\text { parson per day) }\end{array}$ & $\begin{array}{c}\text { Total phosphorus } \\
\text { removal } \\
\text { efflclency }(\%)\end{array}$ \\
\hline Primaly & $\begin{array}{c}\text { no } \\
\text { yes } \\
\text { Average }\end{array}$ & $\begin{array}{c}9 \\
19 \\
28\end{array}$ & $\begin{array}{l}1.71 \\
0.75 \\
1.06\end{array}$ & $\begin{array}{l}36.3 \\
75.5 \\
62.9\end{array}$ \\
\hline Secondary & $\begin{array}{c}\text { no } \\
\text { yes } \\
\text { Average }\end{array}$ & $\begin{array}{l}46 \\
137 \\
183\end{array}$ & $\begin{array}{l}1.03 \\
0.42 \\
0.58\end{array}$ & $\begin{array}{l}59.0 \\
88.4 \\
81.0\end{array}$ \\
\hline Lagoons & $\begin{array}{c}\text { no } \\
\text { yes } \\
\text { Average }\end{array}$ & $\begin{array}{c}45 \\
76 \\
121\end{array}$ & $\begin{array}{l}0.78 \\
0.20 \\
0.42\end{array}$ & $\begin{array}{l}65.5 \\
92.5 \\
\mathbf{8 2 . 4}\end{array}$ \\
\hline Tertiary & $\begin{array}{c}\text { no } \\
\text { yes } \\
\text { Average }\end{array}$ & $\begin{array}{c}2 \\
33 \\
35\end{array}$ & $\begin{array}{l}1.02 \\
0.15 \\
0.20\end{array}$ & $\begin{array}{l}58.7 \\
94.7 \\
92.7\end{array}$ \\
\hline
\end{tabular}

(After: Chambers et al. 2001, Environment Canada) 
Municipal wastewater, or sewage, comes from households, office buildings, and small to medium sized industries and is a complex mixture of suspended solids, microorganisms, and debris; some 200 chemicals have also been identified in this waste stream in Canada (Government of Canada, 1996). The nutrients in this mix come from human waste, household cleaning products such as laundry detergent, automatic dishwashing detergent, general cleaners, and industrial byproducts. Human waste contributes more than $90 \%$ of the household nitrogen loadings, with most of the nitrogen in the form of ammonia. Human waste is also the largest source of phosphorus in sewage, followed by automatic dishwashing detergent. Almost all-municipal wastewater in Canada undergoes one or more of the following levels of treatment:

- Primary treatment, which uses physical processes to remove suspended solids;

- Secondary treatment, which uses biological processes to break down organic material and remove additional suspended solids; and

- Tertiary treatment, which uses advanced chemical or biological treatment to remove specific compounds or materials that remain after secondary treatment.

Some of the nutrients in wastewater can be removed by settling, but a precipitating agent such as alum can also be added at any of these stages to increase phosphate removal. Effective nitrogen removal requires the addition of specialized bacteria and wastewater treatment plants are required to employ advanced nutrients removal facility before discharging their treated water to natural water bodies such as Lake Ontario (Environment Canada, 2001). 


\subsubsection{Pathways of Nutrients:}

Physical, chemical and biological pathways of nutrients are a complex process and are briefly described as below:

Phosphorus: Phosphorus may enter a water body through the inflows, precipitation, dry fallout and from sediments; and it may be removed by sedimentation and through the outflow. The different pathways of phosphorus, nitrogen and carbon in lake metabolism make phosphorus the obvious choice for eutrophication control. A certain reduction of phosphorus input will generally result in a greater reduction in algal biomass compared with the same reduction of nitrogen. Furthermore, the reduction of nitrogen input without a proportional reduction in phosphorus creates low N/P ratio, which favors nitrogen fixing nuisance algae, without any reduction in algal biomass.

Total phosphorus (T-P) is considered the key variable for a practical reason, which includes the fractions of crystalline, occluded, absorbed, particulate organic, soluble organic and soluble inorganic phosphorus. Out of these fractions, the three biologically available phosphorus fractions listed in order of decreasing availability are soluble reactive phosphorus (a mixture of dissolved inorganic and organic species), soluble unreactive phosphorus (some include dissolved phosphorus fed by phosphorus sulfate oxidation, and is available for phytoplankton by enzymatic hydralisation which frees organically bound fractions), and labile phosphorus (associated with soil particles).

Nitrogen: Transformations between various nitrogen compounds in the nitrogen cycle of aquatic ecosystems need a thorough understanding for management of water bodies. Most phytoplankton, which creates nuisance bloom conditions are capable of nitrogen fixation and are not dependant on dissolved combined forms of nitrogen. 
Nitrogen fixation occurs only in bacterial cells (blue green algae are prokaryotic, unlike other phytoplankton which are eukaryotic), however nitrogen fixation is inhibited by high cellular ammonia content.

Of the combined forms of nitrogen the most important are ammonia and nitrate. The reactant (ammonia) is not derived from a respiration process. Decomposition of organic matter results in release and accumulation of ammonia. Ultimate sources of ammonia include nitrogen fixation and assimilation in the aquatic and paralimnetic ecosystem components. Under aerobic conditions, ammonia is oxidized in a two-step process called nitrification, first to nitrite, then to nitrate. Under anaerobic conditions, nitrification of ammonia to nitrate does not occur, and ammonia accumulates often at the bottom of lakes. Much of the historic difficulty with quantifying total oxygen demand (and sizing of aeration systems) can be attributed to this "ammonia anomaly". Total oxygen demand includes respiratory demand and nonrespiratory demand, for example chemosynthesis (http://lakes.chebucto.org/eutro.html\#Introduction) \{Accessed on $12 / 03 / 2003\}$

\subsubsection{Biological Nutrients Removal Processes:}

Biological nutrients removal process involves three basic processes: aerobic, anaerobic and anoxic; these three basic components that form the biological nutrient removal processes were developed in 1960 s, by the virtue of number of theoretical and experimental approaches. This principle can be applied to any wastewater treatment process whether municipal, industrial, or agricultural. Aerobic process occurs in the presence of oxygen and anaerobic occurs in the absence of oxygen. The anoxic process is 
a denitrification process by which nitrate nitrogen is converted to nitrogen gas and combination of aerobic and anoxic processes is essential for nitrogen removal.

Biological phosphorous removal is achieved by exposing microbes to alternating anaerobic and aerobic conditions; this mechanism favors the growth of phosphorus accumulating organisms (PAOs), which are responsible for biological phosphorus removal. However, controversy existed for more than a decade concerning the phosphorus removal mechanisms. While some chemical phosphorus removals occur in systems with anaerobic and anoxic zones, it is now recognized that biological mechanisms are responsible for most of the phosphorus removal. In spite of controversies, research during $1960 \mathrm{~s}$ resulted in the first commercial biological phosphorus removal (BPR) process, the Phostrip process, since then a great deal has been discovered about the mechanisms, microbiology, stoichiometry and kinetics of biological nutrients removal processes.

Common systems for biological phosphorous and nitrogen removal are modifications of activated sludge process and incorporate four features:

i) Flocculent slurry of microorganisms

ii) Quiescent sedimentation

iii) Settled solids recycle and

iv) Solids retention time control

To name few of the prominent BNR processes, which are commonly practiced are: A2/O, Bardenpho, University of Cape Town (UCT) process, Modified University of Cape Town (MUCT) process, Virginia Initiative Plant (VIP) process etc. 
The A2/O system uses a combination of anaerobic, anoxic, and anaerobic cells and works well for high phosphorous wastes. The Bardenpho process uses the following series for treatment of waste: anaerobic, anoxic, aerobic, anoxic, and aerobic. This is the most efficient process for removing high levels of nitrogen and phosphorous while producing the least amount of sludge (Grady Jr et al., 1999).

The following section describes biological process, which encourages the removal of nutrients from wastewater.

\section{I) Nitrification:}

Nitrification is the biological oxidation of ammonia to nitrite and then to the nitrate form. Two major species of microorganisms, which are responsible for the biological oxidation of nitrogen compounds, are Nitrosomonas and Nitrobacter. Nitrosomonas oxidizes ammonia to nitrite. Nitrobacter completes the nitrification process by oxidizing nitrite to nitrate.

Temperature, $\mathrm{pH}$, dissolved oxygen concentration and solids retention time (SRT) are important parameters in nitrification kinetics. The rate of nitrification in an activated sludge system decreases with decreasing temperature. The optimum temperature is between 25 and $35^{\circ} \mathrm{C}$. The optimum $\mathrm{pH}$ for nitrification is in the range of 7.5-9.0. Alkalinity is destroyed by the oxidation of ammonia, thereby reducing the $\mathrm{pH}$.

Aeration partially strips the carbon dioxide from the wastewater thereby reducing alkalinity reduction; however, sufficient alkalinity must remain in the wastewater so as not to depress the $\mathrm{pH}$. 


$$
\begin{aligned}
& 55 \mathrm{NH}_{4}^{+}+76 \mathrm{O}_{2}+109 \mathrm{HCO}_{3}^{--} 54 \mathrm{NO}_{2}^{-}+104 \mathrm{H}_{2} \mathrm{CO}_{3}+57 \mathrm{H}_{2} \mathrm{O}+\mathrm{C}_{5} \mathrm{H}_{7} \mathrm{O}_{2} \mathrm{~N} \text { (Nitrosomonas) } \\
& 400 \mathrm{NO}_{2}{ }^{-}+\mathrm{NH}_{4}{ }^{+}+4 \mathrm{H}_{2} \mathrm{CO}_{3}+\mathrm{HCO}_{3}+119 \mathrm{O}_{2}-400 \mathrm{NO}_{3}{ }^{-}+3 \mathrm{H}_{2} \mathrm{O}+\mathrm{C}_{5} \mathrm{H}_{7} \mathrm{O}_{2} \mathrm{~N} \text { (Nitrobacter) }
\end{aligned}
$$

The nitrification rate is also dependent on the fraction of nitrifying bacteria present in the system. A principal means of increasing the nitrification rate is to increase the fraction of nitrifiers. This can be accomplished by increasing the aeration basin mixed liquor suspended solids (MLSS) concentration, which increases the SRT. Lowering the ratio between five-day $\mathrm{BOD}$ concentration and the total Kjeldahl nitrogen concentration (BOD/TKN) by nitrifying in a separate second stage aeration system would also increase the percentage of nitrifiers and thus the nitrification rate.

\section{II) Denitrification:}

Biological denitrification is a process in which nitrate is reduced to nitrogen gas by microorganisms in the absence of dissolved oxygen. Denitrification can occur provided a sufficient source of nitrate and organic carbons are present.

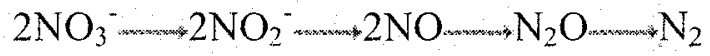

The denitrification process occurs in two steps. The first step involves the reduction of nitrate to nitrite. In the second step nitrite is reduced to produce nitrogen gas. Numerous species of facultative heterotrophic bacteria, including Pseudomonas, Micrococcus, Achromobacter and Bacillus are capable of converting nitrate to nitrogen gas. Nitrate replaces oxygen in the respiratory processes of the organisms capable of denitrification under anoxic conditions. Environmental factors including temperature, $\mathrm{pH}$ and dissolved oxygen concentration have an effect on the rate of denitrification. 
Denitrification occurs at temperatures in the range of $10-30^{\circ} \mathrm{C}$, optimum $\mathrm{pH}$ is in the range of $6.5-8.0$.

\section{III) Phosphorus Removal:}

Phosphorus in wastewater may be present as orthophosphate, polyphosphate or organic phosphorus. Orthophosphate is the more easily removed of the three types of phosphorus. Polyphosphates are converted to orthophosphate by hydrolysis and organic phosphorus is converted to orthophosphate through bacterial decomposition (Process Design Manual for Phosphorus Removal, 1987). Conventional secondary biological treatment systems accomplish partial phosphorus removal by using phosphorus for biomass synthesis during BOD removal. A typical phosphorus content of microbial solids is $1.5-2 \%$ based on dry weight. Wasting of excess microbial solids may result in a total phosphorus removal of $10-30 \%$, depending on the BOD to phosphorus ratio, the system sludge age, sludge handling techniques and side stream return flows.

Additional biological phosphorus removal will occur if the mixed liquor is subjected to both anaerobic and aerobic conditions. When an anaerobic stage precedes an aerobic stage, fermentation products are produced from BOD in the wastewater by the action of facultative organisms. The phosphorus-storing microorganisms are able to assimilate the fermentation products under anaerobic conditions. Because many competing microorganisms cannot function in this manner, the phosphorus microorganisms have a distinct advantage over other organisms in the activated sludge system. Thus, the anaerobic phase results in the development of phosphorus storing microorganisms. 
During the aerobic phase the stored substrate products are depleted and soluble phosphorus is taken up by the microorganisms in quantities greater than what is needed to function. This 'luxury uptake' of phosphorus is maximized at dissolved oxygen concentrations greater than $2 \mathrm{mg} / \mathrm{l}$. At lower DO concentrations the excess phosphorus will be released from the microorganisms.

For biological phosphorus removal to occur, an anaerobic stage is required for the production of the fermentation products. Therefore, if nitrification is occurring, it is necessary for denitrification to take place before enhanced biological phosphorus removal can occur. If this does not happen, and nitrite or nitrates are present, the system is anoxic rather than anaerobic. For this reason, a low dissolved oxygen concentration must be maintained for a longer period when biological phosphorus removal is required than when denitrification is required (Surampalli et al., 1997). 
Table 2.3 Summary of governing actions in the BNR process

\begin{tabular}{|c|c|c|c|}
\hline Particulars & Nitrification & Denitrifcation & Phosphorus removal \\
\hline Action & $\begin{array}{l}\text { Oxidation of } \\
\text { ammonia to nitrite } \\
\text { and then to nitrate }\end{array}$ & $\begin{array}{l}\text { Nitrate is reduced to } \\
\text { nitrogen gas }\end{array}$ & $\begin{array}{l}\text { Orthophosphate, } \\
\text { Polyphosphate or } \\
\text { Organic phosphorus } \\
\text { is removed }\end{array}$ \\
\hline $\begin{array}{l}\text { Dominant } \\
\text { Microorganisms }\end{array}$ & $\begin{array}{l}\text { Nitrosomonas and } \\
\text { Nitrobacter }\end{array}$ & $\begin{array}{l}\text { Pseudomonas, } \\
\text { Micrococcus, } \\
\text { Bascillus and } \\
\text { Achromobacter }\end{array}$ & $\begin{array}{l}\text { Acinobacter } \\
\text { Bacillus cereus } \\
\text { Aeronomas }\end{array}$ \\
\hline Phase & Anaerobic/Aerobic & Anoxic/Aerobic & Anaerobic/Aerobic \\
\hline Optimal pH & $7.5-9.0$ & $6.5-8.0$ & $6.5-7.5$ \\
\hline Optimal Temp ${ }^{\circ} \mathrm{C}$ & $25-35$ & $10-30$ & $10-25$ \\
\hline $\begin{array}{l}\text { Optimal SRT } \\
\text { (days) }\end{array}$ & Greater than 11.0 & Greater than 11.0 & Less than 11.0 \\
\hline $\begin{array}{l}\text { Optimal HRT } \\
\text { (hours) }\end{array}$ & About 2.0 & About 2.0 & Between $6.0-7.0$ \\
\hline $\begin{array}{l}\text { Optimal DO } \\
(\mathrm{mg} / \mathrm{l})\end{array}$ & About 2.0 & About 2.0 & More than 2.0 \\
\hline
\end{tabular}




\subsubsection{Fixed Biofilms:}

Microorganisms in fixed biofilms are grown attached to a solid surface rather than being freely suspended in the wastewater undergoing treatment and this solid surface may be fixed in space with the wastewater flowing over it in thin sheets as in packed tower or it may rotate about an axis, thereby moving through the fluid in the bioreactor as in rotating biological contactors.

Biofilm can be divided in to two zones, the base film and the surface film; both contain an assemblage of microorganisms and other particulate material bound together by a matrix of extra cellular polymers. Base film consists of a structured accumulation, a well-defined boundary with transportation mechanism is through diffusion, and where as surface film provides transition between the base film and the bulk liquid with transportation mechanism being dominated by advection. For a detailed description, rotating biological contactor process is discussed as below (Grady Jr et al., 1999).

\subsection{1(a) Rotating Biological Contactors (RBC):}

Rotating biological contactors are generally made up of circular shaped corrugated plastic media that are mounted on a horizontal shaft and in turn a motor fitted with speed regulator rotates the shaft. Plastic media discs are partially submerged in the wastewater (about $40 \%$ ), and its rotational speed varies from 1-2 revolutions per minute.

Rotating plastic disc media get exposed alternately to wastewater and atmosphere, this helps the growth of microorganisms on the disc and metabolizes biodegradable organic material and nitrogen-containing compounds in the wastewater. When the loading rate of biodegradable organic matter is sufficiently low, nitrifying bacteria will grow on the media \& convert the ammonia- $N$ to nitrate- $N$. 
Many RBC facilities were installed in US during 1970s; over 600 in the US \& 3000 in the World currently exist.

Almost all the manufacturers of RBC units produce standard dimensions; typical media bundle is $3.66 \mathrm{~m}$ in diameter, $7.6 \mathrm{~m}$ long on a shaft that is $8.23 \mathrm{~m}$ long. Typical velocity of $1.6 \mathrm{rpm}$, the peripheral velocity of the disc is $18.3 \mathrm{~m} / \mathrm{min}$. Media material is made of high-density polyethylene containing UV inhibitors such as carbon black and corrugated sheets are used for discs to get higher surface area available.

To minimize the short-circuiting, the axis of each individual RBC shaft is typically placed perpendicular to the direction of flow (Grady Jr et al., 1999). 


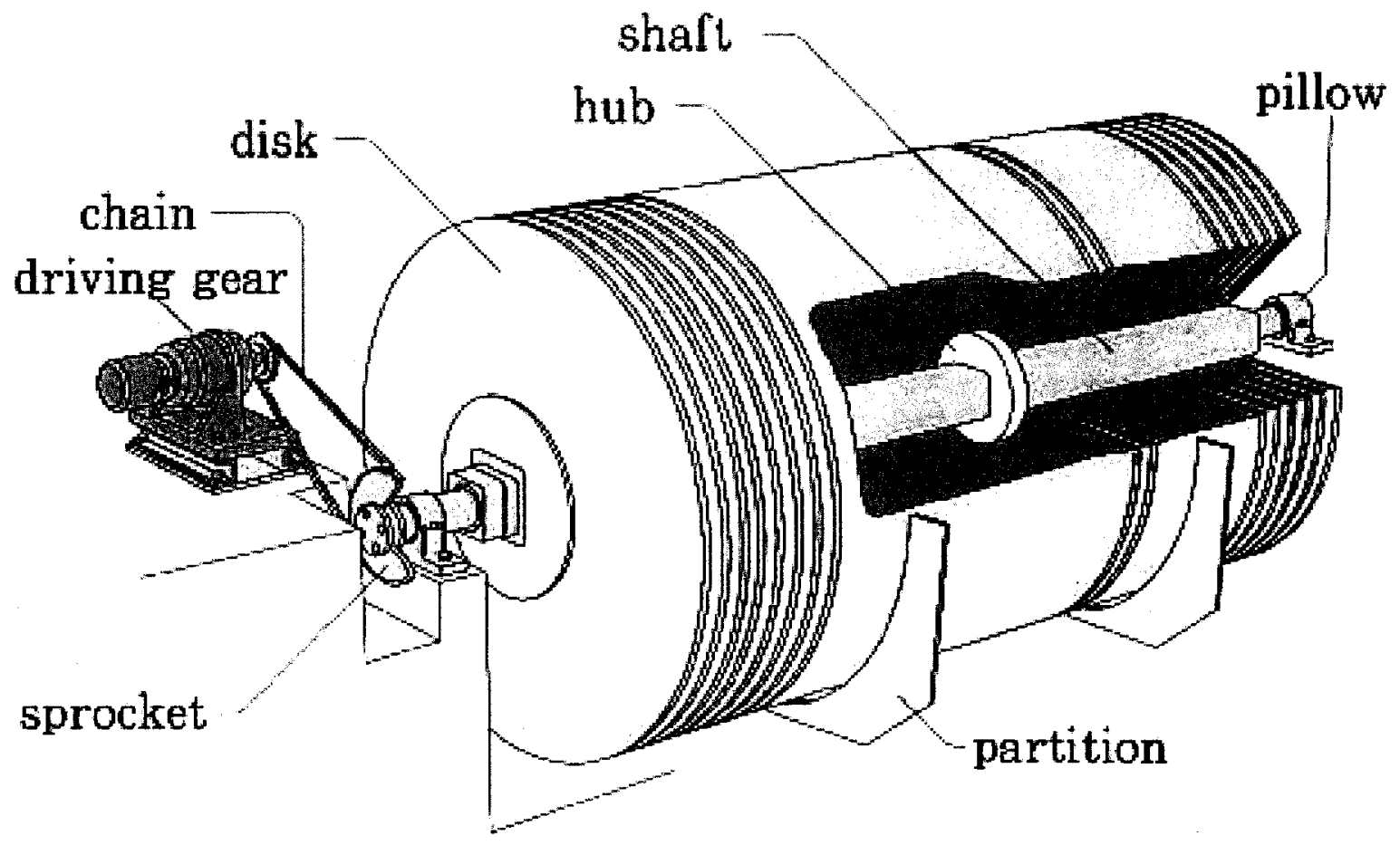

Figure2.2: Schematic View of a RBC Assemblage

\{After: http://nett21.unep.or.jp/jsim\%5Fdata/water/water\%5F1/html/doc\%5F204.html (accessed on 12/03/2003)\}. 


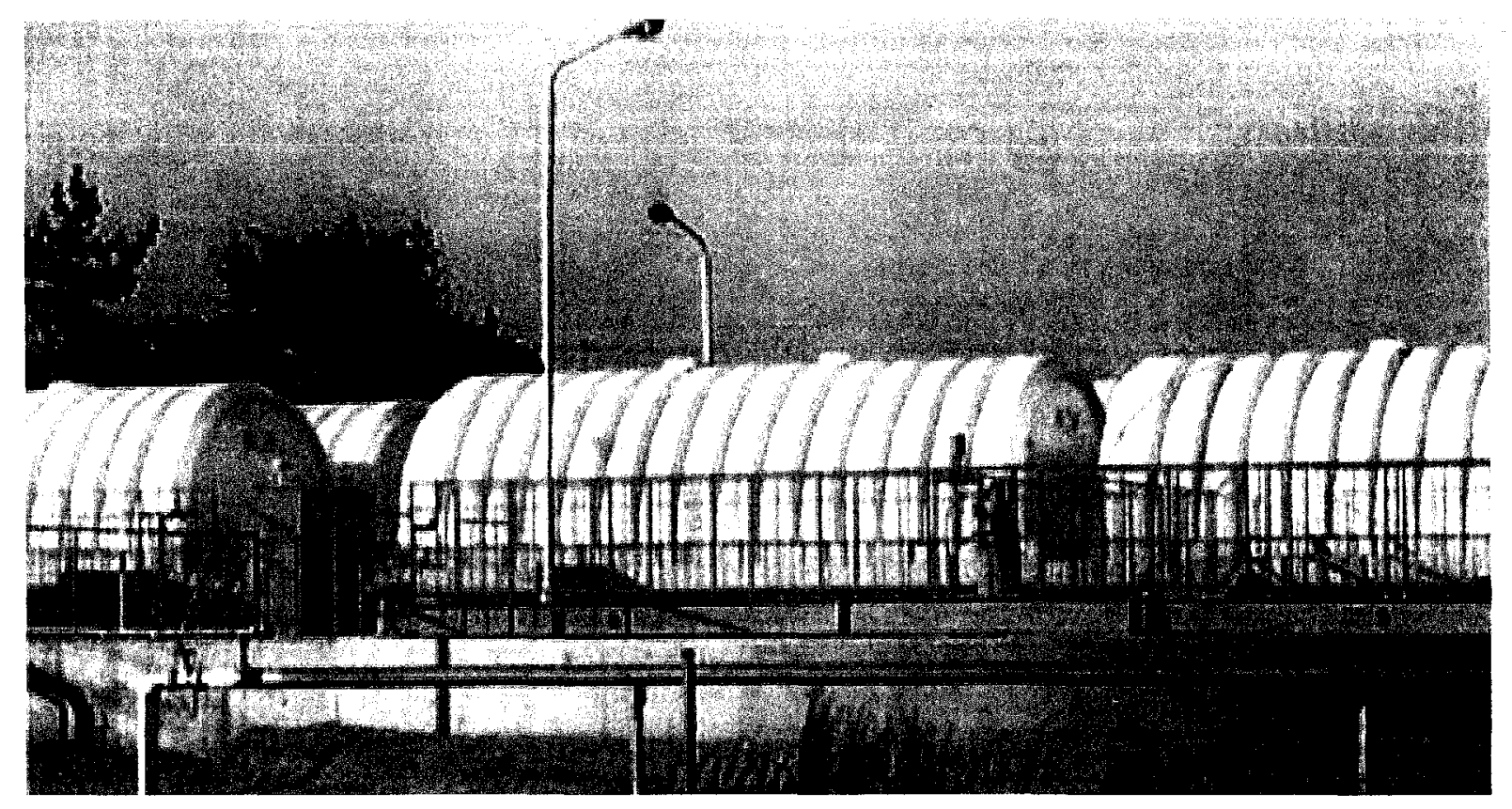

Figure 2.3: Picture shows Array of RBC Discs

\{After:http://nett21.unep.or.jp/jsim\%5Fdata/water/water\%5F1/html/doc\%5F204.html (accessed on 12/03/2003)\} 


\subsubsection{Activated Sludge Processes (AS):}

Activated sludge is an aerobic suspended growth process and microorganisms are grown in a variety of bioreactor configuration, which remove soluble organic matter. Incepted in 1914 by Arden \& Lockett, activated sludge process is the most widely used biological wastewater treatment even today. Common factors governing activated sludge systems are:

i) Flocculent slurry of microorganisms (Mixed Liquor Suspended Solids-MLSS)

ii) Quiescent settling (Hydraulic Retention Time-HRT)

iii) Recycling of settled solids (Return Activated Sludge-RAS)

iv) Removal of excess sludge (Waste Activated Sludge-WAS)

Microorganisms in flocculent slurry remove soluble \& particulate organic matter from the waste influent; quiescent settling helps in reducing the concentration of MLSS, which produces an effluent, low in suspended solids. Settled solids are recycled as concentrated slurry from the clarifier back to the bioreactor and then excess solids are wasted to control solids retention time to have desired value.

The bioreactor containing the MLSS is called as aeration basin and is aerobic throughout. Sufficient mixing energy is required in the bioreactor to maintain the solids in suspension. Concentration of MLSS depends on the characteristics of the influent wastewater, bioreactor hydraulic retention time, and process solids retention time. Return activated sludge is recycled from clarifier to bioreactor and concentration of RAS depends on the clarifier operation conditions, including the influent MLSS and influent RAS flow rate. To maintain desired SRT, solids can be removed from the process at various points and this stream is called waste activated sludge (Grady Jr et al., 1999 and Ganczarczyk, 1983). 


\subsubsection{Biology of Activated Sludge:}

Activated sludge represents a complicated mixture of viruses and other organisms, found either singly or clumped together, often enmeshed in a fabric of organic debris, dead cells and other waste products.

\subsubsection{1(a) Bacteria:}

The most prominent and active bacteria in activated sludge system are heterotrophic and autotrophic, which are both aggregated in the sludge flocs and dispersed in the liquor. The physical characteristics of the treatment system can also affect activated sludge population diversity by a washout of slow-growers, elimination of species more sensitive to turbulence, etc.

Heterotrophic bacteria utilize organic material as a source of both carbon and energy, while autotrophic bacterial generally depend on the oxidation of mineral compounds for energy requirements and utilize carbon dioxide as a carbon source. Bacteria in activated sludge are reproduced by binary fission, with the generation time ranging from less than 20 minutes to a few days (growth pattern can be represented by Buchanan's curve).

Filamentous bacteria such as Sphaerotilus natans, Geotrichum, Beggiatoa and Thiothrix, etc, in activated sludge systems cause sludge bulking, indicating the presence of substrates rich in carbohydrates. 


\subsubsection{1(b) Sludge Age:}

SRT or sludge age $\left(S_{A}\right)$ in activated sludge system can be calculated as

$$
S_{A}=\frac{V X}{Q_{W} Z_{R}+\left(Q-Q_{W}\right) Z_{e}}
$$

Where

$V=$ Volume of aeration basin

$Q=$ Volumetric flow rate of influent

$Q_{V}=$ Volumetric flow rate of wastage

$X=$ Suspended solids in aeration tank

$X_{R}=$ Suspended solids in recycle line

$X_{c}=$ Suspended solids in final effluent (Ganczarczky, 1983).

Conventional activated sludge system was used for retrofitting to remove BOD and Nitrogen simultaneously; this led to compact and cost effective treatment process. In the experimental set up, immobilized nitrifiers to be dosed in a nitrification tank were obtained by molding polymer materials consisting mainly of polyethylene glycol and microorganisms in to $3 \mathrm{~mm}$ square pellets through polymerization reaction. The immobilized pellets homogenized and the numbers of Nitrosomonas and Nitrobacter in the pellets were found to be higher than that of activated sludge, thus, reduces the SRT in the whole reaction system. Even at a lower temperature of about $10 \mathrm{C}, 90 \%$ efficiency in simultaneous removal of $\mathrm{BOD}$ and $\mathrm{N}$ was reported (Emori et al., 1994).

Availability of less organic substrate, coupled with low temperature has reduced the nutrient removal efficiency of treatment plants. Studies have indicated that by 
introducing a sponge-like media in to anoxic zone of activated sludge conditions, temperature effects on nitrification can be reduced. The reduced denitrification rates at low temperature is believed due to higher DO contents in return sludge, together with less organic contents in wastewater and slower microbial reaction itself (Choi et al., 1998).

Group of researchers worked on Mathematical model "Activated Sludge Model No. 2." This model introduces phosphorus-accumulating organisms (PAO) and allows us to simulate the behavior of biological nutrient removal activated sludge systems. Typical wastewater composition and a set of stoichiometric and kinetic parameters are provided to make reasonable predictions (Gujer et al. 1995).

A single compartment tank for pilot experiment was used and air injected by compressor during aeration period. Concentrated synthetic substrate and diluting water were pumped in the activated sludge tank by means of peristaltic pumps. The mixed liquor was passed in front of the DO sensor, which monitored sludge respiration. Exact reaction mechanism was created in time that which would normally take place in real plant using the principle of alternating anaerobic and aerobic phases; this was achieved by sequentially alternating ( 3 cycles/day) the aerated and unaerated phases (Hascoet et al., 1985).

Thorough investigation was done to understand what happens to the phosphorus and its movement during alternating phases. Using electron microscope, a sample of microorganisms taken during an aerated period was observed and it was found that the polyphosphate granules were present inside the cells, as shown in fig 2.7 "a" and " $b$ ". Observation of this sample placed in an anaerobic phase for six hours in the presence of 
carbonaceous organics, showed the complete disappearance of polyphosphate granules in the cells, as shown in figure 2.4 "C'"

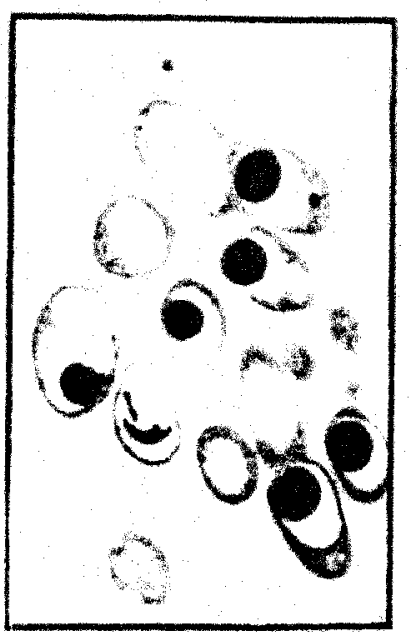

(a)

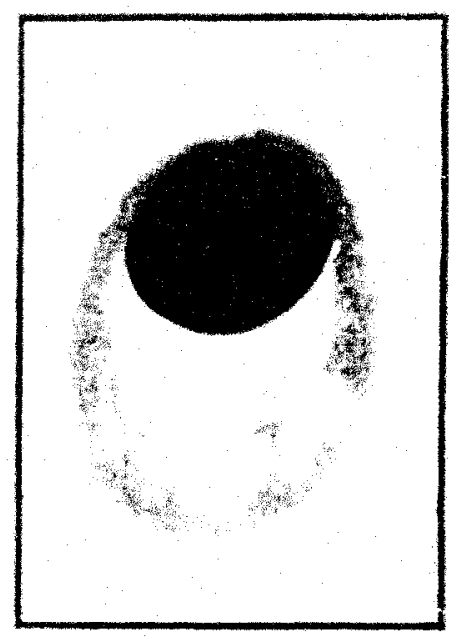

(b)

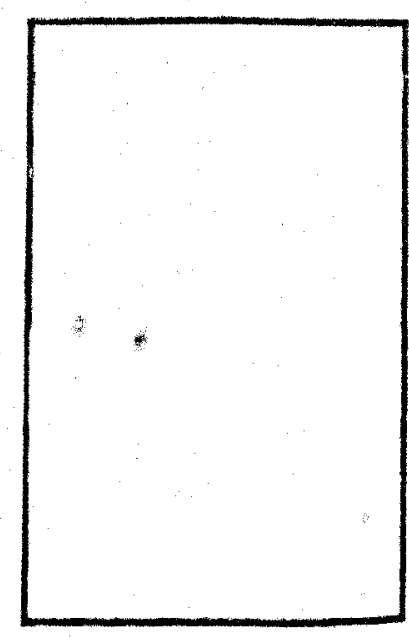

(c)

Figure 2.4: Polyphosphate Granules Inside the Cells (After: Hascoet et al. 1985)

Results obtained in pilot plant with synthetic feed substrate feed, shown that amount of phosphorus removal was 7 times greater than that of theoretically needed for the nutritional requirement of purifying microorganisms, and also the phosphorus content of the sludge was 4 times greater than that of conventional activated sludge (Hascoet et al., 1985). 


\subsubsection{Sequencing Batch Reactor (SBR):}

Sequencing batch reactor derives its name from the sequence of steps that the reactor goes through in entire process of wastewater treatment. Basic steps governing the SBR process are:
i) Filling
ii) Reacting
iii) Settling
iv) Drawing
v) Idling

In filling \& reacting steps, mixing and aeration occur, as this is necessary for biological reaction. Mixing \& aeration is terminated, leading to settling of biomass at settling stage. Treated effluent is removed and then reactor is ready to be placed back for service to receive influent during drawing and idling stages respectively.

Timing allotted for each stages cited above is the most important factor that steers the whole SBR process. The length of the fill period is chosen depending on variety of factors, including the nature of the facility and the treatment objectives. Main effect of the fill period determines the hydraulic characteristics of the bioreactor. If the fill period is short, the process will be characterized by a high instantaneous process-loading factor, exposing the biomass for initial high concentration of organic matter and other wastewater constituents, but over the time the concentration will drop down. On the other hand, if the fill period is long, the biomass will experience only low and relatively constant concentrations of the wastewater constituents. 
The environmental conditions established during the fill and react periods will determine which events occur. If the fill and react periods are aerobic throughout, then oxidation of carbon and nitrification occur, indicating that SBR will behave more or less like activated sludge process. But elimination of aeration while mixing will allow denitrification to occur if the nitrate is present. Furthermore, inclusion of another mixed but unaerated interval later in the react period can make the SBR act like the Bardenpho process. Looking in to above two examples of few combinations, SBR can be designed and operated to mimic many different continuous flow processes. Once the aeration and mixing is completed in react period and allowed to settle, clear effluent suitable for discharge is produced and certain amount of biomass can be retained at this stage in the bioreactor to maintain desired SRT. During draw period, settled effluent is removed by decantation.

Finally, the idle period is allowed in each cycle to provide flexibility and beginning of the new fill period terminates the idle period and initiates new cycle. Based on SBR principle numerous researches are conducted worldwide and are also in progress (Grady Jr et al., 1999).

It has been observed that salinity in the influent wastewater greatly inhibits biological nutrients removal efficiency in SBR and is dominated by the high mol\% $\mathrm{G}+\mathrm{C}$ Gram-positive bacteria. Further, addition of acetate to the process boosted the availability of carbon for the phosphorus accumulating organisms (PAOs); if this was not done, denitrifying bacteria out competed the PAO for carbon source thereby hampering the phosphorus removal in the system (Intrasungkha et al., 1999). 
Temperature effects on the process have been focused and found that biophosphorus removing mechanism still remains partially unresolved, however, the aerobic phosphorus uptake rate showed a maximum in the interval from 15 to $20 \mathrm{C}$. But, nitrification \& denitrification decreased as the temperature decreased; with decreasing temperature, more carbon will be available for poly-phosphate bacteria (Baetens et al., 1999).

Many researchers have studied the optimum level of phosphorus required for efficient removal of organic matter by activated sludge, understanding of this mechanism have lead to know the requirement of minimum concentration of phosphorus in activated sludge which allows the maximum BOD removal without causing any deterioration in the properties of settling sludge.

Oscillation between feast and famine is one of the most common environmental stresses microorganisms are exposed to in SBR system. Two sets of SBR tanks were arranged in series, acidogenic and methanogenic in nature. The operated conditions were effective in removing $97 \%, 75 \%$, and $86 \%$ of Carbon, Nitrogen and Phosphorus respectively. The improvements in the settling sludge allowed a reduction in the settling drawing, and filling times, and increased the anaerobic and aerobic SRT in the cycle configuration.

The results showed that the combination of a two-step anaerobic digester with a SBR is effective for combined carbon, nitrogen and phosphorus removal from industrial wastewaters. The existence of zones in which the different populations coexist is possible through the arrangement of reactors and proposed operational conditions (Rustrian et al., 1998). 


\subsubsection{Hybrid Biological Nutrients Removal (HBNR) Process}

\subsubsection{RBC and Continuous Stirred Tank Reactor:}

Biological nutrient removal systems create anaerobic, anoxic and aerobic phases for phosphorus release, denitrification and nitrification / dephosphoration, respectively, thereby allowing ammonium, oxide nitrogen and phosphorus to be simultaneously removed. But such reactions between various microorganisms lead to complex characteristics in any single sludge process. Conflicts have arisen in the system that removes nitrogen and phosphorus simultaneously.

Choosing a suitable Sludge Retention Time (SRT) for both phosphorus and nitrogen to be removed simultaneously in a single activated sludge process is a major task. Conger SRT with higher dissolved oxygen (DO) are prerequisites for higher efficiency of nitrification. For shorter SRT \& provided extreme anaerobic stage, polyphosphate accumulating organisms (PAOs) can release higher phosphorus level and accumulate more polyphosphate in anaerobic and aerobic stages respectively) These conflicts can be resolved by adopting hybrid biological nutrient removal process (HBNR).

Recent studies have shown that combination of suspension and biofilm growth systems can provide two kinds of bacteria populations in the process: suspended activated sludge bacteria for enhancing phosphorus removal and biofilm bacteria with a long sludge age for improving nitrification. SRT of more than 10 days is required to achieve higher efficiency of nitrogen removal; however, a SRT less than 12 days is deemed necessary to complete the phosphorus removal (Chuang et al., 1997). 
We can briefly explain HBNR mechanism; in the low DO stages, volatile fatty acids (VFA) from the influent and possibly some VFA's formed in this tankage, were taken up and converted to polyhydroxy butyrate (PHB) by microbiological species such as Acinobacter.

In the higher DO, stages PHB is oxidized, as the orthophosphorus is removed from solution and bonded in to molecules that form granules of phosphate within bacteria cells. The stored polyphosphate is removed from the system by wasting a portion of the phosphorus - rich sludge. The remainder of the secondary clarifier solids was recirculated to the $\mathrm{RBC}$ treatment tank influent.

Nitrification could occur in the low DO stage because the biofilm on the rotating media is exposed to the atmospheric oxygen in the air phase of the rotation. Also, the $\mathrm{RBC}$ could be considered as a mechanical aerator device, and draws some oxygen in to mixed liquor as a result of rotation. Denitrification could occur as the oxygen in the mixed liquor is depleted inside the RBC media, as well as in the mixed liquor, which surrounds the fixed film.

There exists a balance between phosphorus removal, nitrification and denitrification. The most desirable situation would be to have the majority of the nitrification / denitrification take place in the phosphorus stress/release stage while phosphorus uptake would occur in the last stage of treatment, when DO is highest (Neu, 1992).

A hybrid system, combining activated sludge and RBC was used to remove nutrients and worked on the kinetics of reactions. 
Organic carbon can be hydrolyzed and fermented by both types' anaerobic bacteria autotrophic and heterotrophic on the submerged portion of RBC to achieve:

i) Increase the Oxygen Demand (OD) and Short-Chain Fatty Acids (SCFA) production as the carbon sources for polyhydroxalkanoates (PHA) storage in the bio-P bacteria and denitrification

ii) Improvement in the efficiency of phosphorus release and denitrification

The relationship between substrate utilization and substrate concentration in the CSTR can be described by an equation similar to Michaelis-Menten equation for enzyme kinetics and can be in the form

$\left(\frac{\mathrm{dS}}{\mathrm{dt}}\right)_{\mathrm{u}}=\mathrm{k} * \frac{\mathrm{Sx}}{\left(\mathrm{K}_{\mathrm{s}}+\mathrm{S}\right)}$

Where

$\left(\frac{\mathrm{dS}}{\mathrm{dt}}\right)_{\mathrm{u}}=$ Substrate utilization rate (mass volume $^{-1}$ time $^{-1}$ )

$\mathrm{x}=$ total biomass concentration (mass volume ${ }^{-1}$ ), including activated sludge and fixed biofilm

$\mathrm{k}=$ maximum specific utilization rate $\left(\mathrm{time}^{-1}\right)$

$\mathrm{S}=$ residual substrate concentration (mass volume ${ }^{-1}$ )

$K_{s}=$ saturation constant

Specific substrate utilization rate $q$ is defined as

$q=\frac{(d S / d t)_{u}}{x}=\mathrm{k} * \frac{\mathrm{S}}{\left(\mathrm{K}_{\mathrm{s}}+\mathrm{S}\right)}$

When $\mathrm{S}>K_{s}, q=k$ 
When $\mathrm{S}<<K_{s}, q=\mathrm{k} * \frac{\mathrm{S}}{\mathrm{K}_{\mathrm{s}}}=K * S$

Where $\mathrm{K}=$ specific substrate utilization rate constant, (volume mass ${ }^{-1}$ time $^{-1}$ ).

Grau (1975) proposed the rate of substrate utilization as

$$
\left(\frac{\mathrm{dS}}{\mathrm{dt}}\right)_{\mathrm{u}}=\mathrm{K}_{1} \mathrm{x}\left(\frac{S}{S_{0}}\right)^{n}
$$

Where $K_{1}=$ specific substrate utilization rate constant by Grau, $\left(\right.$ time $\left.^{-1}\right)$.

When $S_{o}$ is fixed and the reactor is completely mixed, the specific substrate utilization rate $q$ can be rewritten as

$q=K(S e)^{n}$

Where $S e$ is residual substrate in the reactor, (mass volume ${ }^{-1}$ ) and $n$ is the reaction order, and is dimensionless (Su et al. (1996). 


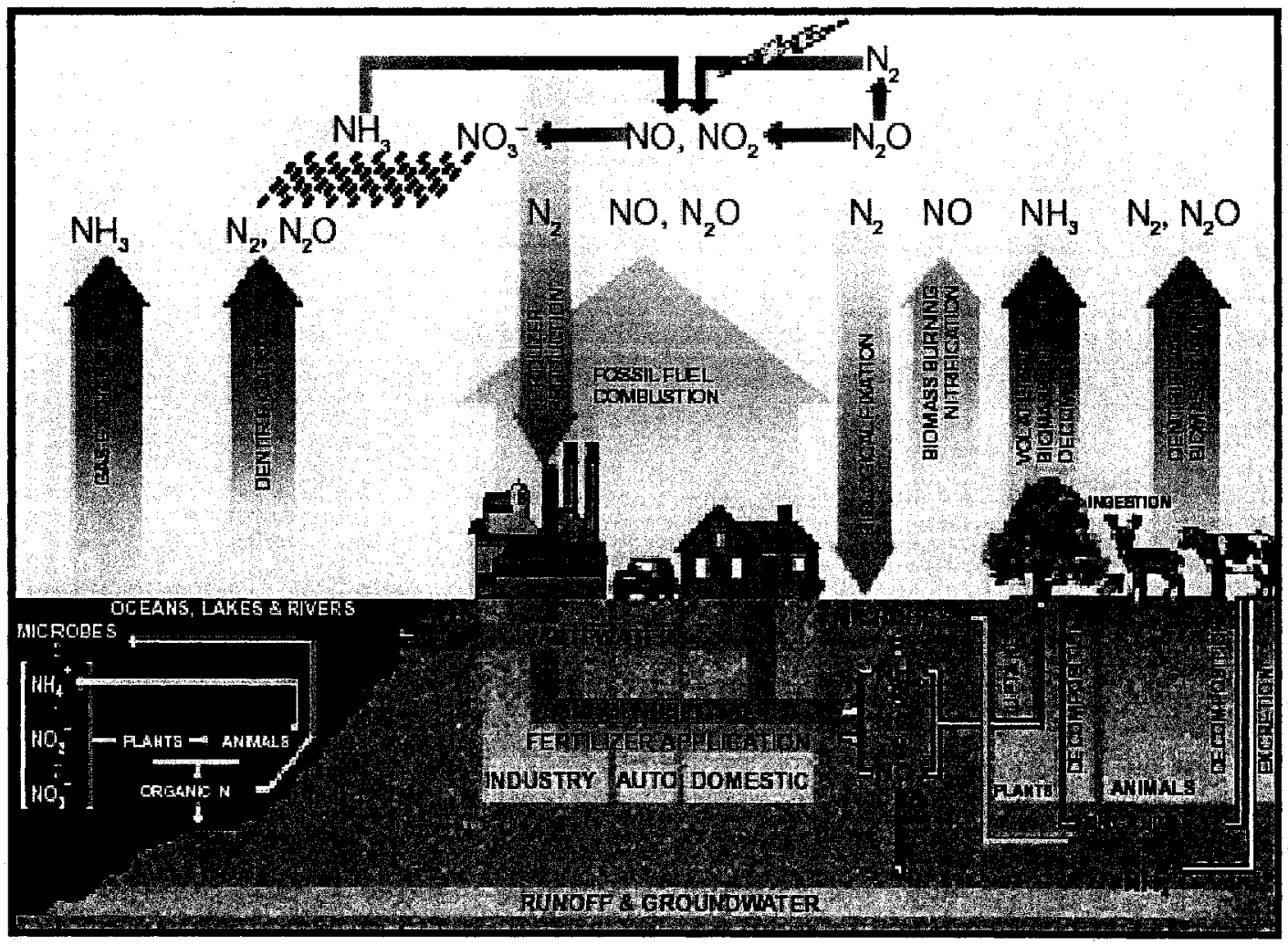

\section{Figure 2.5: Nitrogen Cycle}

(After: Chambers et al. 2001, Environment Canada) 


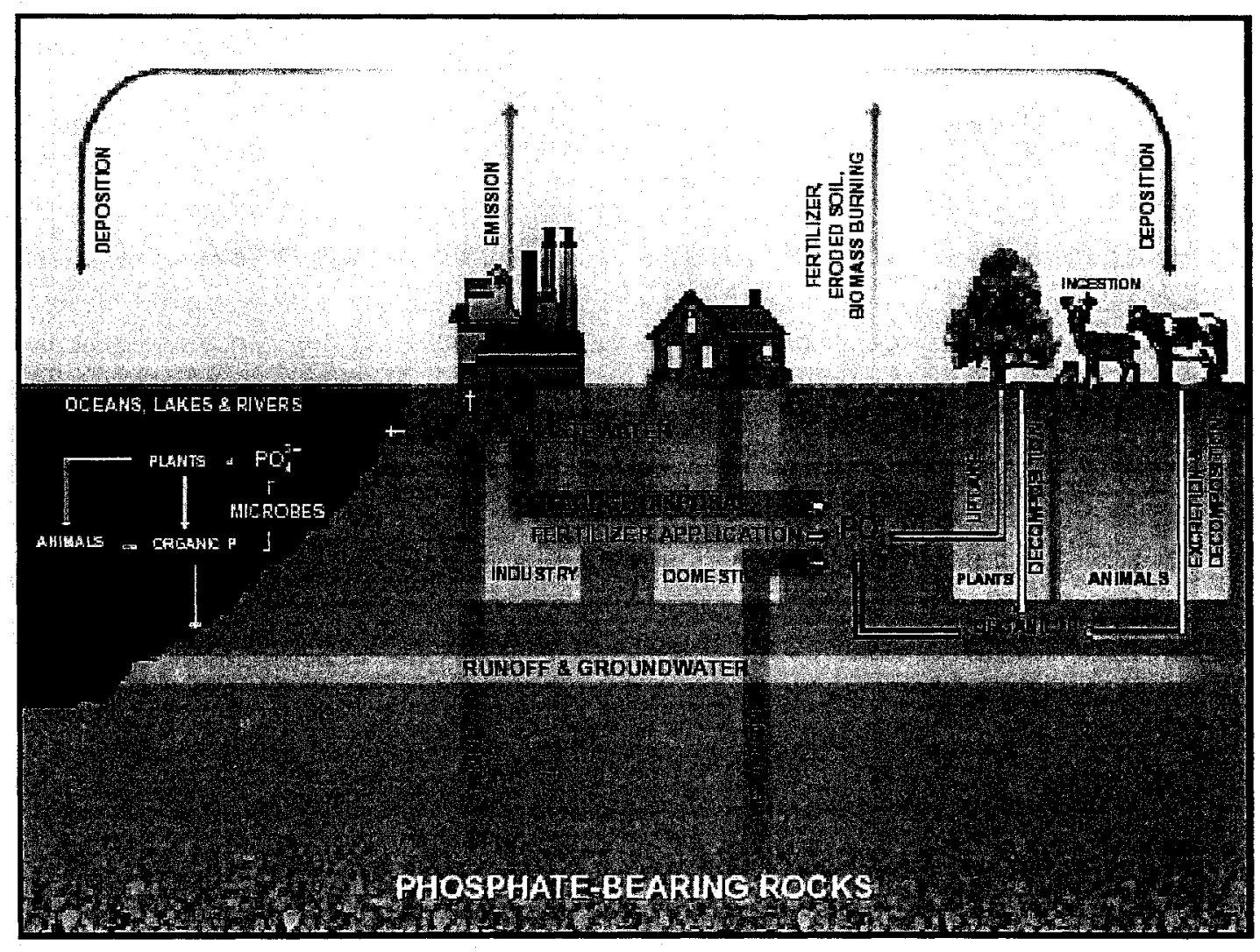

Figure 2.6: Phosphorus Cycle

(After: Chambers et al. 2001, Environment Canada) 


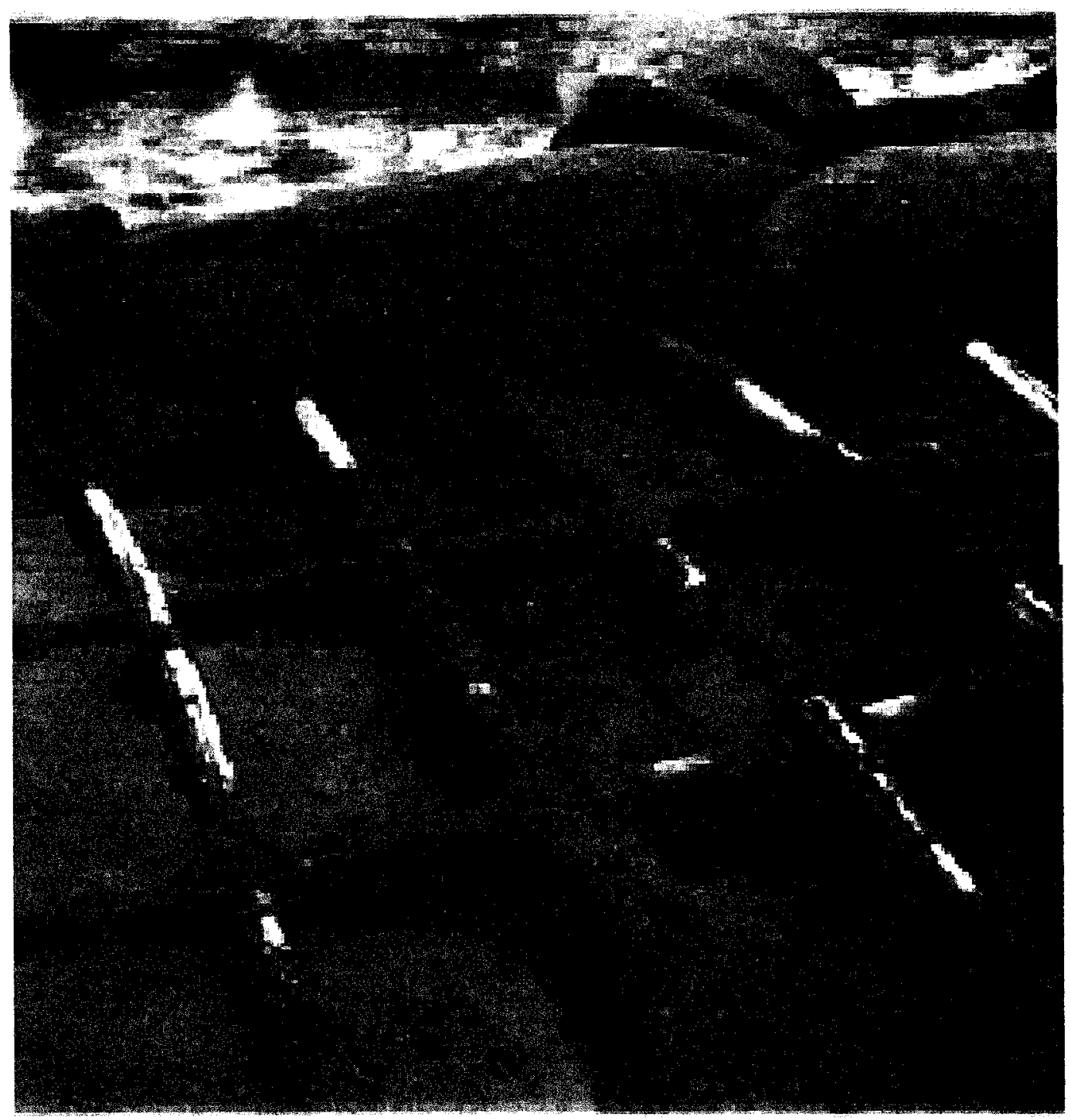

Figure 2.7: Decaying Algae

(After: Filamentous algae, Corel CD photo \#138085, 2001, Environment Canada) 


\section{CHAPTER 3: RECENT RESEARCHES}

Biological nutrients removal processes are preferred over chemical processes because of their low operational costs, easy maintenance and minimal environmental impacts. A conventional wastewater treatment plant can easily be upgraded to include to biological nutrients removal with minimal alteration or addition in the process design.)

Many forms of modified biological nutrients removal processes are designed and operated throughout the world; presently, there is an abundant amount of research under exploration. Most of these methodologies deal with the integration of existing system with the newly developed technologies in order to improve the efficiency of biological removal of nutrients in wastewater treatment plants.

\subsubsection{Nutrients Removal Using Continuous Stirred Tank Reactor:}

Continuous stirred tank reactor (CSTR) is a cylindrical shaped reactor, with a mixing device fitted to a motor of variable speed; where anaerobic, anoxic and aerobic phases of biological nutrients removal may take place (all in a single reactor) under various operational modes of continuous mixing. To make the system anaerobic, nitrogen is pumped continuously and then continuous mixing is introduced to provide anoxic conditions. Once the system is subjected to stipulated periods of time during anaerobic and anoxic phases, nitrogen pumping is stopped and equal amount of oxygen is pumped in to create the aerobic phase. By subjecting the influent wastewater to a cycle of anaerobic, anoxic and aerobic conditions in CSTR, microorganisms are exposed to a favorable environment to enhance nitrification, denitrification and phosphorus removal by means of complex biological mechanisms. 
Chuang et al. (1997) used different DO concentration to improve the nutrient removal efficiency coupled with different HRT and SRT, it was found that variation in DO of influent wastewater has very little effect on the nutrients removal efficiency, but major role player was the SRT of microorganisms.

Bertumen and Musacchio (2000) used CSTR for bench scale experiments and set the objectives of removing nutrients through biological method and retrofitting the system to existing wastewater treatment plants within Greater Toronto Area in Canada. To some extent, the experiment succeeded in removing Nitrogen and Phosphorus, but there was no consistency in the successive trials carried out. Source of organics (COD) was used as a primary variable with time and it was found that there is no direct correlation between the percentages of organics present in the influent wastewater to the nutrient removal efficiency.

Even though the purpose of the bench scale experiment was not to replace any of the existing units from wastewater treatment plants, rather, to be considered as an addition to the prevailing system, but it proved, itself inefficient.

On the other hand, the experimental set up was very economical, used only bacteria cultures and minimal amount of nitrogen gas. It did not call for any harsh chemicals that existing plants utilize, making it environmentally more benign. Also it consumed less power, making its operations very economical one. The system could be retrofitted to existing facility with minimum construction and causing least impacts on the activities of the existing main plant.

Despite inheriting some positive qualities, the feasibility study of the CSTR process could not accomplish its goals. It was revealed that only about $65 \%$ of nitrogen 
and $70 \%$ of phosphorus was removed, which is far less than what the regulation calls for; reasons being given for low performance of the systems were many, but unfortunately not very specific.

But, through the limited literature review within the scope of the studies, one of the possible causes was the complex nature of the bacteria action involved in the mechanism of nutrients removal. As cited earlier in section 2.3.0, different bacteria require different sludge retention timings (higher the sludge retention time, higher the nitrogen removal; where as, more than 11 days of sludge retention time is not favorable to achieve modest amount of phosphorus removal efficiency) to perform the desired action. Hence, it was not possible to give this desired conflicting environment for bacteria in the same reactor without affecting overall plant efficiency.

The possible ways to overcome the obstacles would be:

- Redesigning the generic process

- Addition of a sludge retention unit

- Allocating more time for anaerobic and anoxic phases

- Re-circulation of activated sludge to anaerobic and anoxic phases from sludge retention unit

- Increasing over all HRT and SRT of the entire process

- Conduct more number of trials with much higher levels of influent BOD / COD 


\subsubsection{Hybrid System Using RBC In Anaerobic, Anoxic and Aerobic Phases:}

Many systems have been developed in recent years to rearrange the layout of anaerobic, anoxic and aerobic reactors. Ultimately, a high degree of efficiency in nutrient removal can be achieved through use of four or more stages, some examples, Bardenpho process and Modified University of Cape Town process etc.

However, some conflicts arise when employing such a single sludge system to remove nitrogen and phosphorus simultaneously/ First, the growth of nitrifiers is slower than that of heterotrophic bacteria; therefore, operation using a long sludge retention time (SRT) should be adopted if higher efficiency of nitrogen removal is required. On the other hand, the system must be operated using a shorter SRT if phosphorus removal is to be enhanced) Second, the carbon sources are generally not rich enough for denitrification since the anoxic reactor is typically placed behind the anaerobic reactor and also the short chain fatty acids (SCFA) are utilized primarily for phosphate release in the anaerobic reactor.

Comeau et al. (1986) suggested combining the clarified wastewater emitted from a digested sludge reactor with wastewater influent to increase the amount of SCFA as well as to improve the phosphate release and denitrification rate. Brinch et al. (1994) added hydrolysate from a sludge fermenter to improve the removal efficiency of phosphorus.

A concept called Surfact, first tried in 1975 at Philadelphia in USA, using a system combining $\mathrm{RBC}$ with activated sludge.

In Tokyo, an existing secondary activated sludge wastewater treatment plant was upgraded to remove nitrogen by rearranging the plant layout and adding $\mathrm{RBC}$ to the third 
(aerobic) reactor to improve nitrification, this proved to be a great success considering the space restrictions in countries like Japan (Su et al. 1997).

Su et al. (1996) developed an activated sludge bioreactor system with fully and partially submerged $\mathrm{RBC}$ using three reactors with anaerobic, anoxic and aerobic conditions to remove nitrogen, phosphorus and organics from the municipal wastewater. The authors demonstrated that, biofilm (such as RBC) can be used to resolve the SRT conflicts in the nutrients removal systems by adding a fully submerged RBC in the anaerobic and anoxic reactors to mix suspended solids as well as provide attached beds for anaerobic bacteria. The anaerobic biofilm can hydrolyze the complex and particulate COD to readily biodegradable COD and SCFA. Consequently, the amount of SCFA will be increased to improve both phosphate release and denitrification.)

By locating two stages of partially submerged $\mathrm{RBC}$ in the acrobic basin, the nitrifiers are retained to prolong the SRT of the activated sludge system. Additionally, the function of RBC was to replace the conventional nitrification reactor. Simultaneously, the conflict between nitrogen and phosphorus removal as a function of SRT was resolved.

The detention times of the anoxic and aerobic reactors were $0.41-1.41$ hours for denitrification and $1.35-4.06$ hours for nitrification. Both of these timings were shorter than the conventional treatment process, which could be the result of the denitrifiers and nitrifiers being able to detain a high concentration in the reactor.

The operated SRT was calculated by the method of total biomass in all three reactors divided by the total biomass of the waste sludge. With the total HRT in the range of 8-10 hours and SRT was 10.5-15.6 hours, the average total nitrogen removal was about $70 \%$ and total phosphorus removal was about $95 \%$. 


\section{Drawbacks:}

Though the experimental set up seemed convincing in resolving certain primary conflicts, the biggest draw back of the Su et al. (1996) system was the low removal efficiency of the total nitrogen (about 70\%). Due to increasing stringent guidelines, it is difficult to meet the mandatory requirements by the system.

Also, the whole operation needs more space and power to operate, making it an economically infeasible option over others.

\section{Possible Reasons For Low T-N Removal Efficiency:}

It was suggested ( $\mathrm{Su}$ et al. 1996) that, " the biofilm on the RBC in the anoxic reactor has the same characteristics as those of the biofilm on the aerobic $\mathrm{RBC}$ except the bacteria on the anoxic RBC are dominantly denitrifiers".

The above statement is not fully convincing for the reason that both biofilms are in different environment and also the basic principle of $\mathrm{RBC}$ is to expose the discs alternately to wastewater and atmosphere, this helps the growth of microorganisms on the discs and metabolizes complex biodegradable organic material and nitrogen-containing compounds in the wastewater.

Conversely, a closer observation of the process design diagram reveals that the functional role of fully submerged $\mathrm{RBC}$ at anaerobic and anoxic phases of the reactor was not fully justified. This could be one of the reasons for low-level total nitrogen removal efficiency. By introducing a vigorous mixing environment at the anoxic phase, nitrogen removal efficiency of the process could have been improved. 


\subsubsection{Phosphorus and COD Removals Using Activated Sludge (AS):}

Greenburg et al. (1955) proposed that activated sludge could take up phosphorus at levels beyond the normally accepted microbial growth requirements, and many researchers have pointed that the biological sludge, submitted to cyclic anaerobic, anoxic and aerobic conditions, can accumulate and eliminate phosphorus during aerobic phase, in excess of its normal metabolic requirement.

Choi et al. (1996) adopted an activated sludge process, suitably modified so as to combine anaerobic and aerobic conditions in a single reactor and observed for continuous removal of phosphorus and COD from wastewater with different internal recycle ratios, $\mathrm{N} / \mathrm{P}$ ratios and varying SRT conditions.

A reactor was made of an acrylic column $(10 \mathrm{~cm}$ internal diameter and $145 \mathrm{~cm}$ height) with the inverted cone bottom. The system consists of three main parts such as anaerobic zone in the lower part (at 4 liters level mark), the aerobic zone in the upper part (at 6 liters level mark) and the clarifier in the right upper part (at 1 liter level mark) and the column is marked from $1-11$ liters to take samples at different levels for analysis. The mixing and sludge return in the anaerobic zone were achieved in a single reactor by using a mixing paddle powered by a 4-rpm electric motor. Air was fed through a stone diffuser at 6 liters level from the reactor bottom. The sludge used for continuous tests was obtained from the aerobic plant for municipal wastewater treatment plant of Jungrang, Seoul (South Korea) and this sludge was acclimatized continuously in the synthetic wastewater for 6 weeks, passing through successive anaerobic and aerobic conditions.

During the process, effective uptake of phosphorus took place and activated sludge settled down in the anaerobic zone at the sampling point of 8 liters level. After 
many experiments, an HRT of 11 hours and anaerobic recycle rate of $200 \%$ of the influent flow rate were selected.

It was demonstrated that presence of $\mathrm{NOx}-\mathrm{N}\left(\mathrm{NO}_{3}-\mathrm{N}\right.$ and $\left.\mathrm{NO}_{2}-\mathrm{N}\right)$ hampered the release of phosphorus in the aerobic zone, as did the presence of molecular oxygen, and reduced the uptake of phosphorus in the aerobic zone. Based on the aerobic zone volume, an SRT of 10 days produced a highest percentage of T-P (94\%) and COD (95\%) removals, where aerobic internal recycle rate was $100 \%$.

\section{Draw Backs:}

Although the scope of the experimentation did not include nitrogen removal, the principle is very much relevant and forms core design in chapter 4 for the design and operation of proposed experimentation, hence the methodology is discussed.

It is evident from the above results that, a high rate of phosphorus and COD removal was achieved. However, in today's evolving technologies, this concept of removing only phosphorus (no simultaneous removal of nitrogen) proves to be insufficient as a whole, when there are stringent regulations to restrict the amount of nutrients present in the treated wastewater before discharging in to the receiving water bodies.

\section{Possible ways to incorporate this design for nutrients removal:}

- The same system can be made use to remove nitrogen and phosphorus simultaneously by incorporating an anoxic phase within the reactor by stopping air supply, and nitrogen removal efficiency could be observed

- From literature review, it is extensively discussed that the reaction between various microorganism populations lead to a complex characteristics of this kind 
of single-sludge system, hence there is a need of different reactors for the growth of different bacteria to achieve maximum nutrients removal efficiency.

- Addition of one more rector with $\mathrm{RBC}$ mounted to provide higher sludge age for bacteria would be ideal to achieve the task.

- Adequately controlling the process during anaerobic/anoxic phosphorus uptake, i.e., using nitrate as an electron acceptor can become a pertinent topic of the combined process design \& operation. 


\section{CHAPTER 4: EXPERIMENTATION}

\subsubsection{Background of Hybrid System Combining CSTR and RBC Reactors:}

In urbanized regions and small communities, it is difficult to secure a space and much needed capital to construct a new treatment plant The proposed process does not separate anaerobic and anoxic zones, thus, contributing together with the reduced total site space, to substantially reducing the investment costs for full-scale plants, and also, $\mathrm{RBC}$ reactor can be housed in the modified process design of existing aerobic zones of a conventional wastewater treatment plants. Therefore a system, which occupies lesser space and yet efficiently removes the nutrients from municipal wastewater treatment plants has been thought and proposed hereunder.

In chapter3, various most recent methodologies of hybrid systems for nutrients removal have been discussed in length and throughout the literature review as cited in the chapter2, no documentation exists that has used CSTR in combination with RBC to explore the possibility of enhancing the nutrients removal efficiency by this hybrid process.

Biological nutrients removal systems are among the most complicated biochemical operations devised for wastewater treatment, and like the activated sludge systems from which they were derived, they come in a number of configurations.

The proposed hybrid biological nutrients removal process is essentially an activated sludge system employing CSTR and RBC, in which anaerobic, anoxic and aerobic phases encourage the growth of specialized phosphorus storing, nitrifying and denitrifying bacteria with cell recycling for the purpose of maintaining required concentration of microorganisms. 
Aerobic breakdown of insoluble organic matter in a suspended growth reactor is called aerobic digestion, and árobic digesters generally employ a CSTR with a long retention time, allowing ample time for the conversion of much organic matter in to carbon dioxide and also for nitrification/Anoxic/aerobic digestion cycles the biomass between anoxic and aerobic conditions to use nitrate formed during nitrification as an electron acceptor in place of oxygen, thereby reducing the cost of aeration and $\mathrm{pH}$ controls.

Whereas, in rotating biological contactor, microorganism growth attached to rotating disc accomplish the desired objectives by the same mechanisms used in suspended growth system (for example CSTR), but in a more efficient manner because oxygen transfer is accomplished by the rotation of discs, which are only half submerged in the to be treated wastewater. 


\subsubsection{Impacts of Adverse Bacteria:}

Not all bacteria are beneficial in biochemical operations; some are a nuisance, two forms of nuisance bacteria can grow in aerobic/anoxic systems:

i) Filamentous: this grows as long strands, or filaments, which become intermeshed with biofloc particles and interfere with sedimentation. They are called filamentous bacteria. Although a small number of filaments can provide strength for the biofloc, preventing its disruption by fluid shear forces, too many can act to hold the biofloc particles apart. When this occurs, sedimentation is very inefficient and the biomass will not compact into a sufficiently small volume to allow discharge of a clear effluent.

ii) Foam: another kind of nuisance bacteria forms copious quantities of foam in bioreactors that are being aerated for oxygen transfer. The foam can become so deep as to completely cover both the aeration and sedimentation basins, thereby disrupting treatment and posing a danger to plant personnel. The most common nuisance organisms in anaerobic systems are the sulfate-reducing bacteria. It is generally desirable to design anaerobic operations to produce methane because it is a valuable product. If a wastewater contains high concentrations of sulfate, however, sulfate-reducing bacteria will compete for the electron donor, producing sulfide as a product. This not only reduces the amount of methane produced, but also results in a product that is both dangerous and undesirable in most situations; hence, it is essential to be aware of the growth characteristics of such nuisance organisms so that systems that discourage or prevent their growth can be designed (Leslie Jr et al., 1999). 


\subsubsection{Microbial Community: Perception and Reality}

Microbial communities in biochemical operations are very complex, involving many trophic levels and many genera and species within a trophic level. Unfortunately, most studies on community structure have been descriptive and the exact roles of many organisms have not even been defined, much less quantified. This is slowly changing, but many researches still reflect only the procaryotic portion of the community, and its divisions are usually limited to major groups, such as aerobic heterotrophs, floc-formers, denitrifiers, nitrifiers, PAOs, etc.

However, regardless of the nature and complexity of the microbial community involved, there are certain fundamental processes that occur universally in biochemical operations. The relative importance of these processes, and hence the outcome from a biochemical operation depends on the physical configuration of the operation and the manner in which it is operated. Designer's ability to select and design the appropriate biochemical operation for a specific task depends on ones recognition of the importance of the various processes in it and the capability for quantitatively expressing the rates of these processes (Leslie Jr et al., 1999). 


\subsubsection{Design Process for Combined CSTR and RBC Reactors:}

\subsubsection{Different Approaches:}

Some conflicts have arisen in single system that simultaneously removes nitrogen and phosphorous, as discussed in chapters 2 and 3 ; therefore, resolving these conflicts and enhancing the process performance are the primary goal of this modified system.

Selecting the sludge retention time of a process is a major task in BNR processes (Su et al. 1996). Ammonium nitrogen can theoretically be removed by aerobic nitrification, followed by anoxic denitrification. In the sequence reactions, the autotrophic nitrifier's nitrification is normally a limiting reaction on nitrogen removal. A longer SRT and higher dissolved oxygen conditions become prerequisites for improving nitrification.

However, phosphorus removal capacity corresponds to the amount of waste sludge and its phosphorus content. For a shorter SRT and provided extreme anaerobic stage, polyphosphate accumulating organisms (PAOs) can release a higher phosphorus level and accumulate more polyphosphate in anaerobic and aerobic stages, respectively. The process during a shorter SRT yields a better performance in terms of phosphorus removal (Chuang et al. 1997).

Consequently, the difficulties in selecting SRT and DO arise which simultaneously remove nitrogen and phosphorus. Modifying the process design using CSTR and RBC can eliminate these difficulties.

The combined system will provide two kinds of bacteria populations in the process: suspended activated sludge bacteria (in CSTR reactor) for enhancing the phosphorus removal and biofilm bacteria (in $\mathrm{RBC}$ reactor) with a longer sludge age for 
improving the nitrification, thus, combined system looks highly promising in simultaneously removing nitrogen and phosphorus.

This process requires less space, and it can be retrofitted to existing wastewater treatment plants with minimum changes in process design, thereby saving in huge capital cost. 


\subsubsection{Materials and Methods:}

As illustrated in figure5.1, an existing CSTR reactor at Civil Engineering Dept of Ryerson University, Canada, can be used, in which the combined activated sludge-RBC process can be modified.

CSTR reactor: Cylindrical shape, flat base with mixing facility

$\mathrm{RBC}$ reactor: Rectangular shape

The hybrid process is comprised of conventional anaerobic-anoxic-aerobic activated sludge and a RBC only in the aerobic stage, as illustrated in figure 5.1. This process will provide a longer sludge age for bacteria in the RBC biofilm. The effluent and sludge samples can be collected from one of the wastewater treatment plants in Greater Toronto Area (GTA), after activating the sludge by passing through successive cycles of anaerobic, anoxic and aerobic phases, required microorganisms are inoculated. These bacteria are starved and then fed on the sample wastewater to get acclimatized by passing continuously through anaerobic and anoxic phases.

The effective volume of the CSTR and RBC reactors shall be 15 liters and 45 liters respectively (1:3 ratios). The $\mathrm{RBC}$ disks are made of $\mathrm{PVC}$, diameter $300 \mathrm{~mm}$, thickness $2 \mathrm{~mm}$ each piece and 8 pieces on the shaft. The total surface area and submerged ratio of $\mathrm{RBC}$ shall be $1.13 \mathrm{~m} 2$ and $40 \%$ respectively. A variable speed motor device drives RBC and the speed of the RBC disk shall be about 10.5 meters per minute. The influent wastewater can be brought from Bay plant of GTA and is analyzed as per standard methods of APHA for all the parameters. 


\subsubsection{Detailed Steps of Procedure:}

1) Influent wastewater is to be analyzed for initial concentrations of Nitrogen, Phosphorus, Temp, $\mathrm{pH}, \mathrm{COD}, \mathrm{BOD}$, total concentration of MLSS and are entered in the sample data table

2) Introduce the sample to CSTR and RBC tank, and fill the system with sample to the required level (@15 liters)

3) Anaerobic phase: Keep the CSTR in anaerobic condition by continuous pumping of Nitrogen gas@30L/h and mixing is neglected and this phase will continue for 120 minutes

4) Anoxic phase: Nitrogen pumping is continued at the same rate and stirring of the sample begins@500 rpm; this phase will continue for 120 minutes

5) Aerobic phase: Begins at the end of anoxic phase, and oxygen is pumped in to the CSTR at the rate of $30 \mathrm{~L} / \mathrm{h}$, and duration of this phase is 360 minutes

6) $\mathrm{RBC}$ remains aerobic for the entire period of experiments and oxygen is pumped from the bottom of the tank using air jets at the rate of $30 \mathrm{~L} / \mathrm{h}$

7) Only $40 \%$ of the discs are submerged in the sample at RBC tank and rotating speed of the discs are maintained at 10.5 meters per minute

8) By adjusting the Anaerobic and Anoxic periods in CSTR for the time of 120 minutes each, and a total HRT of 10 hours, the recirculation of the sample continues throughout for the SRT of 12 days.

9) $\mathrm{pH}$ will be maintained between $6.5-8.5$ throughout by using $\mathrm{NaOH}$ of $0.5 \mathrm{~N} \mathrm{HCl}$ solutions and will not be allowed to deviate more than 0.5

10) Experiment will be conducted at a room temperature ranging from 21 to $23 \mathrm{C}$ 
11) Concentration of COD is maintained throughout at $2 \mathrm{mg} / \mathrm{L}$ by introducing acetate time to time

12) To maintain the optimum balance of incoming food from the influent wastewater and the population of microorganisms, a portion of microorganisms is discarded each day; and is termed as waste activated sludge (WAS)

13) Samples are taken and analyzed for every 12 hours from the day one till 7 days

14) Samples are taken for every 6 hours from the 8th day till 12 days

15) Recycling of return activated sludge (RAS) is 0.25 times the influent flow.

16) All the samples are analyzed for Nitrogen, Phosphorus and COD each time and plotted against the graphs as Concentration Vs Time.

17) Once the cycle of 12 days SRT is completed, waste activated sludge will be analyzed for Nitrogen, Phosphorus and COD concentration to reconfirm the results obtained from the treated effluent.

Collecting and Analyzing Samples: Effluent samples can be collected and analyzed as per the Standard procedure of APHA. 


\subsubsection{Equipments required:}

1) CSTR unit

2) $\mathrm{RBC}$ unit

3) Electro spectrometer

4) Inoculators

5) Sludge activation units (jars with stirrer)

6) Oven

7) Laboratory test tubes, jars etc

8) $\mathrm{pH}$ meter

9) Oxygen cylinder

10) Nitrogen gas cylinder

11) Chemicals

12) Bacteria cultivation (acinobacters, heterotrophs etc)

13) Sludge from wastewater treatment plant to grow bacteria within the Laboratory

14) Related safety equipments, and other necessary tools. 


\subsubsection{Protocol for the Analysis:}

Following equations are used to calculate the typical parameters, which are found in Appendix A.

For mathematical analysis, the data needed are surface area of CSTR and RBC tanks, average flow in to the system and the specific concentrations of the incoming wastewater.

If the average flow, $Q_{o}\left(\frac{m^{3}}{d}\right)$, is divided by the total surface area of the tanks, As (m2), regardless of the tank shapes, the surface overflow rate $S Q R\left(\frac{m^{3}}{d}\right)$, can be determined:

$$
S Q R=\frac{Q_{o}}{A_{s}}
$$

By using the removal efficiency chart in Appendix A, along with the given concentrations of BOD5 and SS, a corresponding percentage removal for each can be read. This value is the percent of BOD5 or SS removed.

It is now easy to calculate the amount of BOD5, and SS entering HBNR process as:

BOD5= Initial BOD5 (1-\% removed)

But we know that the, flow entering the HBNR process is the same as that which entered the system initially.

Therefore, so far, we have the amount of BOD, SS and flow entering. Let us term parameters as below:

$Q_{o}=$ Average flow 


\section{$S_{o}=$ Influent concentration of soluble BOD5}

$X_{o}=$ Influent concentration of microorganisms

For these calculations, it can be assumed that the amount of influent soluble BOD5 is equal to the BOD5 value entering HBNR process. While the microorganisms in the effluent are measured as suspended solids, this is the SS value entering HBNR process.

The soluble concentration is found using the equation:

$$
\mathrm{S}=\frac{K_{s}\left(1+K_{d} \theta_{c}\right)}{\theta_{c}\left(\mu_{m}-K_{d}\right)-1}
$$

Where:

$\mathrm{S}=$ Soluble BOD5 in aeration tank and in effluent, $\left(\frac{m g}{L}\right)$

$K_{s}=$ Half velocity constant; concentration of soluble BOD5 at half the maximum growth rate, $\left(\frac{m g}{L}\right)$

$K_{d}=$ Decay rate of microorganisms, $\left(d^{-1}\right)$

$\theta_{c}=$ Mean cell-cell resistance time, $(\mathrm{h})$

$\mu_{m}=$ Maximum growth rate constant, $\left(d^{-1}\right)$

These parameters values used can be taken as the typical values, Appendix $A$, in order to calculate S.

Concentration of microorganisms in aeration tank $\mathrm{X}$ is $\left(\frac{m g}{L}\right)$ is calculated as:

$$
X=\frac{\theta_{c} Y\left(S_{o}-S\right)}{\theta\left(1+K_{d} \theta_{c}\right)}
$$

This equation gives the amount of mixed liquor suspended solids (MLSS). 
Next step is to determine how much of the suspended solids is in the mixed liquor $\left(X^{\prime}\right)$

$$
X^{\prime}=1.25 X
$$

The sludge volume index can be used to help determine the characteristics of the settled sludge, which will have an impact on the return rates and the suspended solids in the mixed liquor.

Amount of return sludge can be calculated as:

$$
X_{R}^{\prime}=\frac{10^{6}}{S V I}
$$

$X_{R}^{\prime}=$ Maximum concentration of return sludge $\left(\frac{m g}{L}\right)$

$X S V I=$ Sludge volume index $\left(\frac{m g}{L}\right)$

We can also assume that $X^{\prime} R$ is approximately $80 \%$ of the return MLSS, or in other words:

$$
X_{R}^{\prime}=1.25 X_{R}
$$

Therefore, the flow rate of the wasting sludge can be calculated as:

$$
Q_{w}=\frac{\forall X}{\theta_{c} X_{R}}
$$

Where:

$Q_{w}=$ Rate of flow of liquid containing microorganisms to be wasted $\left(\frac{\mathrm{m}^{3}}{d}\right)$

$\forall=$ Volume of aeration tank $\left(\mathrm{m}^{3}\right)$

Assuming that suspended solids in the effluent are negligible, we can calculate flow rate of return sludge as below: 
$Q_{R}=\frac{Q X^{\prime}-Q_{w} X^{\prime} R-\left(Q-Q_{w}\right) X_{e}}{X^{\prime} R-X^{\prime}}$

Where:

$Q_{R}=$ Estimated flow rate of return sludge $\left(\frac{\mathrm{m}^{3}}{d}\right)$

$Q=$ Average flow, $Q_{o},\left(\frac{m^{3}}{d}\right)$

$X_{e}=$ Concentration of microorganisms in the effluent from the secondary settling tank $(\mathrm{mg} / \mathrm{L})$ and is assumed to be zero (Bertumen, 2000). 


\subsection{0: Typical Case for Mathematical Modeling of Biological Nutrients Removal Using CSTR and RBC}

Assume that a bioreactor with a volume of 1 liter, with a configuration as presented in figure 5.1 is used to treat a wastewater with a composition as presented in table 5.1. Note that the influent contains a soluble biodegradable substrate (acetic acid) as well as inert organic and inert inorganic particulate material.

\section{[Notes: Assumed essential characteristics of Biological N\&P removal process are:}

- Biomass must be cycled between anaerobic (no oxygen or nitrate present) and aerobic conditions.

- Influent wastewater must contain volatile fatty acids (VFAs), such as acetic acid.

- Influent must be directed to anaerobic zone of the system.

- Anaerobic zone must be protected from ingress of oxygen (aerobic conditions) and nitrate (anoxic conditions)

$\mathbf{F}=$ Influent Flow Rate

$\mathbf{F}_{\mathbf{W}}=$ Wastage Flow Rate

$\mathbf{X}_{\mathbf{B}, \mathbf{H}}=$ Heterotrophic Biomass Concentration

$\mathbf{X}_{\mathbf{D}}=$ Biomass Debris Concentration

$S_{\mathrm{So}}=$ Influent Substrate Concentration

$\mathbf{S}_{\mathrm{S}}=$ Substrate Concentration in Reactor] 
(1) INFLUENT ENTRY

(2) ELECTRICAL MBTDR

(3) SHAFT

(4) STIRRER

(5) CSTR
(6) FLOW FROM CSTR TO RBC

(7) BAFrLE CHAMBER TD AVOID UPWARD FLLV (8) AIR DifTusing SYSTEM

(9) recirculatign of activated sludge

(10) DVER FLOW SYSTEM FGR TREATED EFFLUENT
(11) SETILING SLUBGC IN RBC REACTOR

(1) RBC REACTOR

(13) RBC DISKS

(14) WASTE SLUDGE DISPOSAL

(15) TREAFED EFFLUENT DISPISAL

(16) DXYGEN IS PUMPED IN

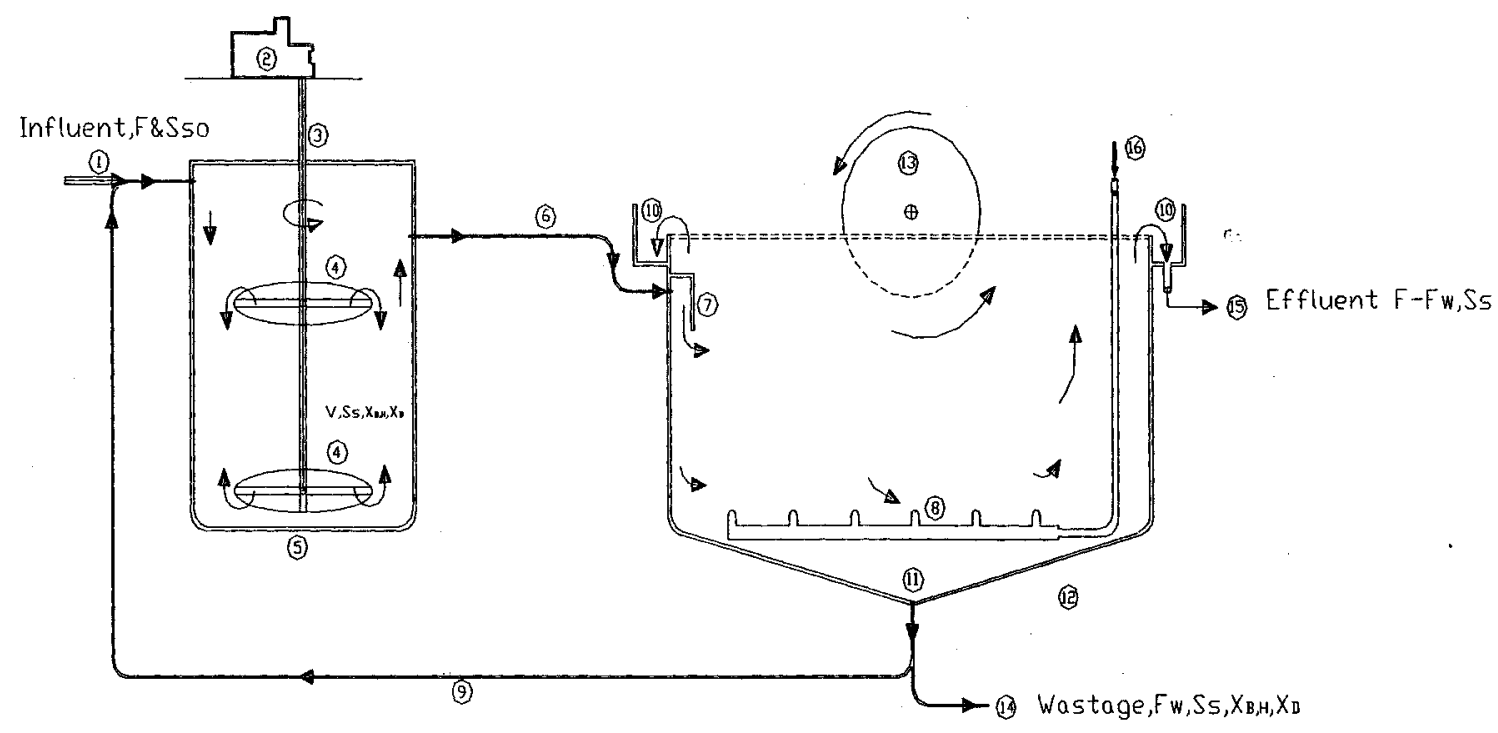

Figure 5.1 Schematic View of CSTR and RBC Hybrid System 
Table 5.1: Wastewater composition

\begin{tabular}{|l|l|}
\hline Flow (L/day) & 6 liters/day \\
\hline Acetic acid (mg-COD/L) & $400 \mathrm{mg}-\mathrm{COD} / \mathrm{L}$ \\
\hline Inert particulate organic compounds $\left(\mathrm{X}_{\mathrm{l}}\right) \mathrm{mg-COD} / \mathrm{L}$ & $50 \mathrm{mg}-\mathrm{COD} / \mathrm{L}$ \\
\hline Inert inorganic suspended solids & $25 \mathrm{mg}-\mathrm{TSS} / \mathrm{L}$ \\
\hline
\end{tabular}

The bioreactor is operated at a temperature of $20^{\circ} \mathrm{C}$ and the kinetic and stoichiometric parameters describing heterotrophic growth for the system are presented in Table 5.2

Table 5.2: Kinetic and stoichiometric parameters for heterotrophic growth

\begin{tabular}{|l|l|}
\hline Maximum specific growth rate $\left(\mu_{\mathrm{H}}\right)$ as a function of & $6.00 \times 1.08^{(T-20)}$ \\
temperatureday ${ }^{-1}$ & \\
\hline Half saturation for substrate $\left(\mathrm{K}_{\mathrm{s}}\right) \mathrm{mg-COD} / \mathrm{L}$ & 20 \\
\hline Decay rate $\left(\mathrm{b}_{\mathrm{H}}\right)$ day $^{-1}$ & $0.18 \times 1.04^{(\mathrm{T}-20)}$ \\
\hline True yield $\left(\mathrm{Y}_{\mathrm{H}}\right), \mathrm{mg}$ biomass-COD/mg-COD removed & 0.60 \\
\hline Inactive fraction $\left(\mathrm{f}_{\mathrm{n}}\right) \mathrm{mg}$ biomass debris-COD/mg biomass-COD & 0.20 \\
\hline
\end{tabular}

The following conversion factors can be used to transform units for all the particulate organic fractions in the system:

- $\mathrm{COD} / \mathrm{VSS}=1.42 \mathrm{mg}-\mathrm{COD} / \mathrm{mg}-\mathrm{VSS}$

- $\mathrm{VSS} / \mathrm{TSS}=0.90 \mathrm{mg}-\mathrm{VSS} / \mathrm{mg}-\mathrm{TSS}$

- Assume that biomass composition is $\mathrm{C}_{5} \mathrm{H}_{7} \mathrm{O}_{2} \mathrm{~N}$ 


\section{With the information presented above, calculate:}

- Minimum SRT to prevent wash-out of the culture

- Minimum acetic acid concentration that can be achieved in the effluent

- The required SRT to achieve an effluent concentration of $1 \mathrm{mg}-\mathrm{COD} / \mathrm{L}$

- With the SRT determined above, calculate:

- Active biomass concentration in the bioreactor (in $\mathrm{mg}-\mathrm{COD} / \mathrm{L}$, as well as $\mathrm{mg}$ $\mathrm{TSS} / \mathrm{L})$

- Debris concentration in the bioreactor (in $\mathrm{mg}-\mathrm{COD} / \mathrm{L}$, as well as $\mathrm{mg}-\mathrm{TSS} / \mathrm{L}$ )

- Concentration of inert organic and inorganic material in the bioreactor

- The total biomass concentration in the bioreactor (in $\mathrm{mg-COD} / \mathrm{L}$, as well as $\mathrm{mg}$ TSS/L)

- The active fraction of biomass in the bioreactor.

- The observed yield, in $\mathrm{mg}$ biomass-COD/mg substrate-COD removed as well as in $\mathrm{mg}$-TSS formed/ $\mathrm{mg}$ substrate-COD removed

- The total mass of biomass wasted (in mass of COD per time and mass of suspended solids per unit of time)

- Calculate the oxygen requirements for the operation of this reactor.

- Calculate the amount of nitrogen that needs to be provided to the system (as mass of nitrogen per unit of time).

- Calculate the amount of phosphorus that needs to be provided to the system (as mass of phosphorus per unit of time). 


\section{Analysis:}

- Calculating the minimum SRT by using the following information:

$$
\Theta_{M I N}=\frac{K_{S}+S_{S O}}{S_{S O}\left(\mu^{\wedge}{ }{ }-b_{H}\right)-K_{S}-b_{H}}=\frac{20+40}{400 *(6-0.18)-20 * 0.18}=0.18 \mathrm{days}
$$

This is the minimum SRT at which the bioreactor can be operated to prevent the washout of bacteria, i.e., washout occurs when the effluent concentration for the substrate (acetic acid) is equal to the influent substrate concentration, and the Monod expression has the growth rate being evaluated at the influent substrate concentration, and making the Monod equation equal to

$$
\mu_{\max }=\frac{1}{\Theta_{c \min }}+b_{H}
$$

- A minimum amount of substrate will have to be present in the bioreactor to drive growth of the organisms, at least at the same rate as death. The effluent substrate concentration is given by

$$
S_{S}=\frac{K_{S}\left(\frac{1}{\Theta_{C}}+b_{H}\right)}{\mu^{\wedge}{ }_{n}-\left(\frac{1}{\Theta_{C}}+b_{H}\right)}
$$

The minimum effluent substrate concentration can be calculated by determining the limit of the effluent substrate concentrations as the SRT approaches infinity:

$$
S_{S \min }=\lim _{\Theta c \rightarrow \infty}\left[S_{S}=\frac{K_{S}\left(\frac{1}{\Theta_{C}}+b_{H}\right)}{\mu_{\|}^{\wedge}-\left(\frac{1}{\Theta_{C}}+b_{H}\right)}\right]=\frac{K S^{*} b H}{\mu^{\wedge}{ }_{n}-b H}=\frac{20 * 0.18}{6-0.18}=0.62 m g-C O D / L
$$


- The effluent substrate concentration is related to the SRT at witch the bioreactor is operated through:

$$
S_{S}=\frac{K_{S}\left(\frac{1}{\Theta_{C}}+b_{H}\right)}{\mu^{\wedge}{ }_{n}-\left(\frac{1}{\Theta_{C}}+b_{H}\right)}
$$

Substituting for the values in the case study:

$$
1=\frac{20\left(\frac{1}{\Theta_{C}}+0.18\right)}{6-\left(\frac{1}{\Theta_{C}}+0.18\right)}
$$

and it can be solved for: $\Theta_{C}=9.46$ days

- The active biomass concentration is given by:

$$
X_{B H}=\left(\frac{\Theta_{C}}{\tau}\right) \frac{Y_{H}\left(S_{S O}-S_{S}\right)}{1+b_{H} * \Theta_{C}}
$$

We know that the volume of the bioreactor is 1 liter, and the influent flow rate is 6 liters per day, so we can calculate the HRT:

$$
\tau=\left(\frac{V}{F}\right)=\frac{1}{6}=0.166 d a y
$$

Then the biomass concentration can be calculated as:

$$
X_{k I I}=\left(\frac{9.46}{0.166}\right) \frac{0.6(400-1)}{1+0.18 * 9.46}=5030 \mathrm{mg} \cdot \mathrm{COD} / \mathrm{L}
$$

To convert to $\mathrm{mg}$-VSS and $\mathrm{mg}-\mathrm{TSS} / \mathrm{L}$, use the conversion factors given above.

$$
X_{B H . V S S}=5030 m g-C O D / L \times\left(\frac{m g-V S S}{1.42 m g-C O D}\right)=3542 m g-V S S / L
$$




$$
X_{B H . T S S}=3542 m g-V S S / L \times\left(\frac{m g-T S S}{0.90 m g-V S S}\right)=3935 m g-T S S / L
$$

- To calculate the biomass debris:

$$
X_{D}=\left(\frac{\Theta_{C}}{\tau}\right)\left[\frac{f_{D} b_{H} \Theta_{C} Y_{H}\left(S_{S O}-S_{S}\right)}{1+b_{H} \Theta_{C}}\right]=\left(\frac{9.46}{0.166}\right) \frac{0.20 * 0.18 * 9.46 * 0.6(400-1)}{1+0.18 * 9.46}=1719 \mathrm{mg} . \mathrm{COD} / \mathrm{L}
$$

Applying the same conversion factor as above:

$$
\begin{aligned}
& X_{D . Y S S}=1719 m g-C O D / L \times\left(\frac{m g-V S S}{1.42 m g-C O D}\right)=1211 m g-V S S / L \\
& X_{D T S S}=1211 \mathrm{mg}-V S S / L \times\left(\frac{m g-T S S}{0.90 m g-V S S}\right)=1346 m g-T S S / L
\end{aligned}
$$

- Inert organic material:

$X_{I}=\left(\frac{\Theta_{C}}{\tau}\right) X_{10}=\left(\frac{9.46}{0.166}\right) 50=2850 m g-C O D / L$

Applying the same conversion factor as above:

$$
\begin{aligned}
& X_{l}=\left(\frac{\Theta_{C}}{\tau}\right) X_{I o}=\left(\frac{9.46}{0.166}\right) 50=2850 m g-C O D / L \\
& X_{\text {L.SS }}=2850 m g-C O D / L \times \frac{m g-V S S}{1.42 m g-C O D}=2007 m g-V S S / L \\
& X_{\text {I.TSS }}=2007 m g-V S S / L \times \frac{m g-T S S}{0.90 m g-V S S}=2230 m g-T S S / L
\end{aligned}
$$

- Inert inorganic material:

$I S S=\left(\frac{9.46}{0.166}\right) 25=1425 m g-T S S / L$ 
- Total biomass concentration and active Fraction:

There are two ways of expressing the active fraction: either in terms of COD, or in terms of TSS. Note that in the first case, the ISS is not considered, since it does not have a COD associated with it, since it is inorganic in nature.

Active fraction on a COD basis:

$$
f_{A}=\frac{X_{B H}}{X_{B H}+X_{D}+X_{S}}=\frac{5030}{5030+1719+2850}=0.52
$$

Note that the denominator of the equation above is equal to the total COD concentration in the bioreactor:

$X_{T C O D}=9600 \mathrm{mg}-\mathrm{COD} / \mathrm{L}$

Active fraction on a TSS basis:

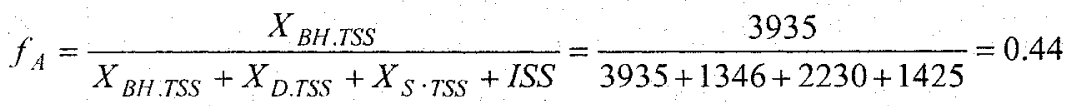

Note that the denominator of the equation above is equal to the total solids concentration (MLSS) in the bioreactor:

$X_{\text {TTSS }}=8936 \mathrm{mg}-\mathrm{TSS} / \mathrm{L}$

Also note that the active fraction, on a TSS basis, is lower than on a COD basis. This is due to the presence of the inert inorganic material.

- Calculation of the observed yield involves calculating the amount of mass formed per day (either in terms of COD or TSS) and dividing it by the mass of substrate removed.

Let's do first the calculation for COD basis. The mass of COD associated with the solids formed in the reactor per day is equal to the total mass of COD associated with the 
solids leaving the bioreactor through the wastage stream (since we do not have any solids leaving the effluent from the bioreactor).

$$
\text { Mass of Solids Wasted per Day COD }=\left(X_{B H}+X_{D}+X_{I}\right) F_{W}=9600 F_{W}
$$

We have calculated the concentration of the different fractions, now need to calculate the wastage flow, and this can be obtained through the definition of SRT:

$$
\Theta_{C}=\frac{V \cdot X_{B H}}{F_{W} \cdot X_{W}}=\frac{V \cdot X_{T}}{F_{W} \cdot X_{W T}}
$$

Note that the SRT is expressed as the solids retention time.

Since the wastage is done directly from the bioreactor, $X_{T}=X_{W T}$. Therefore:

$\Theta_{C}=\frac{V}{F_{W}}$ or $F_{W}=\frac{V}{\Theta_{C}}=\frac{1}{9.46}=0.106 \mathrm{~L} / \mathrm{day}$

So the total mass of solids wasted per day is equal to $9600 * 0.106=1018 \mathrm{mg}$ $\mathrm{COD} /$ day

On a TSS basis, mass of solids wasted per day is equal to $8936 * 0.106=947 \mathrm{mg}$ TSS/day

The mass of substrate removed per day is equal to $\mathrm{F}(\mathrm{Ss}-\mathrm{Ss} 0)=6^{*}(400-1)=2394$ $\mathrm{mg-COD} /$ day

The observed yield on a COD basis is $1018 / 2394=0.43 \mathrm{mg}-\mathrm{COD} / \mathrm{mg}-\mathrm{COD}$

The observed yield on a TSS basis is 947/2394 $=0.40 \mathrm{mg}$-TSS/mg-COD

- Wasted solids calculated in bullet immediately above.

- The oxygen requirements can be calculated using:

$$
R O=F^{*}\left(S_{S O}-S_{S}\right)\left[1-\frac{\left(1+f_{D} * b_{H} \Theta_{C}\right)^{*} Y_{H}}{1+b_{H} \Theta_{C}}\right]
$$

Substituting with the values:

$$
R O=6 *(400-1)\left[1-\frac{(1+0.2 * 0.18 * 9.46) * 0.6}{1+0.18 * 9.46}\right]=1681.6 m g O_{2} / d a y
$$


It could also be calculated by doing a COD balance across the reactor.

$R O=F^{*} S_{S O}-F^{*} S_{S}-F_{W} * X_{T}$

However, note that if we are including XI as part of XT, then to do a COD balance, the equation above needs to be changed to include the addition of $\mathrm{X}_{\mathrm{I}}$ in the feed:

$R O=F^{*}\left(S_{S O}+X_{l}-S_{S}\right)-F_{W} * X_{T}=6(400+50-1)-0.106 * 9600=1676 m g-O_{2} /$ day

The small difference between the two COD balances is due to rounding errors, since the numbers for SRT and Fw had to be truncated.

- The nitrogen requirements can be calculated as:

$$
N R=0.087 * \frac{\left(1+f_{D} * b_{H} \Theta_{C}\right) * Y_{H}}{1+b_{H} \cdot \Theta_{C}}=0.087 * \frac{(1+0.2 * 0.18 * 9.46) 0.6}{1+0.18 * 9.46}=0.026 \mathrm{mg}-\mathrm{N} / \mathrm{mg}-\mathrm{COD}
$$

Since we know how much substrate was removed $6^{*}(400-1)=2394 \mathrm{mg}-\mathrm{COD} /$ day, then the total amount of nitrogen that needs to be supplied to the system is

\section{$0.026 * 2394=62.2 \mathrm{mg}-\mathrm{N} / \mathrm{day}$}

- The mass of phosphorus that needs to be provided to the system is $1 / 5^{\text {th }}$ of the amount of nitrogen [Because, there is always a certain amount of phosphorus that is used to synthesize new heterotrophic biomass (bugs that remove COD), typically about $1 / 5$ of nitrogen requirements] or $62.2 / 5=12.4 \mathrm{mg}-\mathrm{P} / \mathrm{day}$.

(Leslie Jr et al., 1999 and Gujer et al., 1995) 


\section{CHAPTER6: RESULTS AND CONCLUSION}

\subsection{0: Expected Results:}

COD removal: Large quantity of COD is expected to be absorbed and/or uptaken on activated sludge in the anaerobic stage; and residual $\mathrm{COD}$ is therefore can be anticipated to be limited to anoxic or aerobic stage, regardless of the extent to which SRT and $\mathrm{DO}$ are varied. In addition, $\mathrm{COD}$ sequestered at anoxic stage would influence the phosphorus removal in the process.

Nitrogen removal: Already we have understood from the literature review that total nitrogen removal heavily relies on the process SRT. The total nitrogen concentration of effluent would be lower when the operated SRT is more than 10 days, hence removal efficiency of $90 \%$ and above of total nitrogen is fairly anticipated.

Phosphorus removal: It is expected that the sludge of SRT 10 days would yield higher phosphorus release and excess uptake than other SRTs in the anaerobic and aerobic phases respectively.

Polyhydroxyalkanoates (PHA) is a stored carbon and energy sources for polyphosphate accumulating organisms (PAO) on phosphorus uptake and PHA utilization is closely related to phosphorus uptake, both in the anoxic and aerobic stages. The trend of PAOs to consume stored PHAs for phosphorus uptake is expected. Anoxic phosphorus uptake phenomena enhances the phosphorus removal efficiency in the hybrid system and expected removal efficiency of total phosphorus in the process is $95 \%$ and above. 


\subsection{0: Conclusion and Recommendation}

Due to limited scope of the work, validification of the discussed hybrid system is not verified by experimentation to compare the results with those of theoretical ones.

It would be a worthwhile effort to fabricate the equipments and conduct the experimentation as discussed earlier, hence, recommended. 


\section{REFERENCES}

Baetens, D., Vanrolleghem, P.A., van Loosdrecht, M.C.M. and Hosten, L.H. (1999)."Temperature Effects in Bio-P Removal", Water Science Technologv.Vol.39, No.1,pp.215-225.

Bertumen, Joanne. (2000). "The Feasibility of an Advanced Biological Treatment Process in Existing Wastewater Treatment Plants", Undergraduate Thesis, Ryerson University, Toronto.

Choi, Euiso., Rhu, Daewhan., Yun, Zuwhan. and Lee, Euisin. (1998)."Temperature Effects on Biological Nutrient Removal Systems with Weak Municipal Wastewater", Water Science Technology. Vol.37, No.9, pp.219-226.

Chuang, S.H., Ouyang, C.F., Yuang, H.C. and You, S.J. (1997). "Effects of SRT and DO On Nutrient Removal In a Combined AS-Biofilm Process", Water Science Technology. Vol.36, No.12, pp.19-27.

Chuang, Shun-Hsing., Ouyang, Chiao-Fuei. And Wang, Yeuh-Bin. (1996). "Kinetic Competition Between Phosphorus Release and Denitrification on Sludge Under Anoxic Condition", Water Science Technology. Vol.30, No.12, pp.2961-2968.

Choi, Yong Su., Shin, Eung Bai, and Lee, Young Dae. (1996). "Biological Phosphorus Removal From Wastewater In a Single Reactor Combining Anaerobic \& Aerobic Conditions", Water Science Technology.Vol.34, No.1-2, pp.179-186

Emori, Hiroyshi., Nakamura, Hiroki., Sumino, Tatsuo., Takeshima, Tadashi,, Motegi, Katsuzo. And Tanaka , Kazuhiro. (1994). "High Rate and Compact Single Sludge Pre-Denitrifcation Process for Retrofit", Water Science Technology.Vol.30, No.6, pp.31-40. 
Environment Canada, Environment Indicators and Assessment Office, Ecosystem Science Directorate, Environmental Conservation Service (2001). "Nutrients in the Canadian Environment: Reporting on State of Canada's Environment", pp. 13-65.

Fdz-Polanco, Fernando., Fdz-Polanco, Maria., Fernandez, Neivy., Uruena, Miguel A., Gracia, Pedro A. and Villaverde, Santiago. (2001). "New Process for Simultaneous Removal of Nitrogen and Sulphur Under Anaerobic Conditions" Water Research. Vol.35, No.4, pp.1111-1114.

Ganczarczyk, Jerzy J. (1983). "Activated Sludge Process, Theory and Practice", Published by Marcel Dekker, Inc, New York.

Goncalves, R.F., Le Grand, L. and Rogalla F. (1994). "Biological Phosphorus Uptake in Submerged Biofilters with Nitrogen Removal", Water Science Technology: Vol.29, No.10-11, pp.135-143.

Grady, C.P. L. Jr., Daigger, Glent T., Lim, Henry C. (1999). "Biological Waste Water Treatment", Second edition. Published by Marcel Dekker, Inc, New York, pp. 25555.

Gujer, W., Henze, M., Mino, T., Matsuo, T., Wentzel, M.C. and Marais, G. v. R. (1995): "The Activated Sludge Model No. 2: Biological Phosphorus Removal", Water Science Technology. Vol.31 No.2, pp. 1-11.

Hascoet M.C., Florentz, M. and Granger, P. (1985). "Biochemical Aspects of Enhanced Biological Phosphorus Removal From Wastewater", Water Science Technology. Vol.17, No:11-12, pp.233-241. 
Hesselmann, R.P.X., Von Rummell, R., Resnick, Sol M., Hany, R. and Zehnder, A.J.B. (2000). "Anaerobic Metabolism of Bacteria Performing Enhanced Biological Phosphate Removal", Water Research. Vol.34, No.14, pp.3487-3494.

Intrasungkha, Nugul., Keller, Jurg. And Blackall, Linda. L. (1999). "Biological Nutrient Removal Efficiency in Treatment of Saline Wastewater", Water Science Technology. Vol.39, No.6, pp.183-190.

Kabu ,T., Wachtmeister, A., van Loosdrecht M.C. M. and Heijnen, J.J. (1994). "Effects of Nitrate on Phosphorus Release in Biological Phosphorus Removal Systems", Water Science Technology. Vol.30, No.6, pp.263- 269.

Lindrea, K.C., Pigdon, S.P., Boyd, B. and Lockwood, G.A. (1994). "Biomass Characterization in a Nitrification-Denitrification Biological Enhanced Phosphorus Removal (NDBEPR) Plant During Start -Up and Subsequent Periods of Good \& Poor Phosphorus Removal", Water Science Technology. Vol.29, No.7, pp.91-100.

Musacchio, Vince (2000). " Removal of Nitrogen and Phosphorus From Wastewater Using Biological Methods", Undergraduate Thesis, Civil Engg Dept. Ryerson University, Toronto.

Neu, K.E. (1992). "Achievement of Biological Nutrient Removal in Full-Scale Rotating Biological Contactor Wastewater Treatment Plant", Water Science Technology. Vol.26, No.5-6, pp.1115-1124.

Patureau, D., Helloin E., Rustrian E., Bouchez T., Delgenes, J.P. and Moletta, R. (2001). “Combined Phosphate and Nitrogen Removal in a Sequencing Batch Reactor Using the Aerobic Denitrifier, Microvirgula Aerodenitrificans", Water Research . Vol.35, No.1, pp.189-197. 
Rustrian, Elena., Delgenes, Jean Philippe., Bernet, Nicolas. And Moletta, Rene. (1998). "Simultaneous Removal of Carbon, Nitrogen and Phosphorus from Wastewater by Coupling Two-Step Anaerobic Digestion with a Sequencing Batch Reactor", Journal of Chemical Technology and Biotechnology. No.73, pp. 421-431.

Solley, David. And Barr, Keith. (1999). “Optimize What You Have First! Low Cost Upgrading of Plants for Improved Nutrient Removal", Water Science Technology. Vol.39, No.6, pp.127-134.

Su, J.L. and Ouyang, C.F. (1996). "Nutrient Removal Using a Combined ProcessWith Activated Sludge \& Fixed Biofilm", Water Science Technology.Vol.34, No.1-2, pp.477-486.

Su, Jau-Lang. and Ouyang, Chaio-Fuei. (1997). "Advanced Biological Enhanced Nutrient Removal Processes by the Addition of Rotating Biological Contactors", Water Science Technology.Vol.35, No.8, pp.153-160.

Surampalli, Rao.Y., Tyagi, R.D., Karl, Scheible. O. \& Heidman, James. A. (1997). "Nitrification, Denitrification and Phosphorus Removal in Sequencing Batch Reactors",Bioresource Technology.Vol.61, pp.151-157.

Van Benthum, W.A.J., Garrido J.M., Mathijssen, J.P.M., Sunde, J., van Loosdrecht M.C.M. and Heijnen, J.J. (1998). "Nitrogen Removal in a Intermittently Aerated Biofilm Airlift Reactor", Journal of Environmental Engineering. Vol.124, No.3, pp.239-248. 